TECHNICAL PROGRESS IN SPANISH BANKING: 1985-1994*

\author{
Joaquín Maudos, José Manuel Pastor and Javier Quesada**
}

WP-EC 96-06

- Thanks for financial support are due to Instituto Valenciano de Investigaciones Económicas (IVIE), which Financial Economics research area is sponsored by Caja de Ahorros del Mediterráneo and CICYT PB95-1523. Authors also thank the comments received at the Workshop "Productivity, Efficiency and Profitability in Banking" organized by the IVIE, specially comments by David B. Humphrey and Francisco Pérez, the comments received at 12th International Conference in Finance, Association Francaise of Finance (Burdeos, France), as well as the comments received by an anonymous referee. We thank V. Cuñat for his help with the data. Remaining errors are ours. Correspondence: Dpto. Análisis Económico, Universidad de Valencia, Avda. Blasco Ibañez - 32, 46010 Valencia (SPAIN), Tel: 34-6-386.44.08 / Fax: 34-6-360.06.08. e-mail: pastorj@mozart.econom.uv.es.

" Joaquín Maudos and José Manuel Pastor, University of Valencia; Javier Quesada. University of Valencia and IVIE. 


\section{Editor: Instituto Valenciano de}

Investigaciones Económicas, S.A.

Primera Edición Abril 1996.

ISBN: 84-482-1221-5

Depósito Legal: V-1484-1996

Impreso por Copisteria Sanchis, S.L., Quart. 121-bajo, 46008-Valencia.

Impreso en España. 


\title{
TECHNICAL PROGRESS IN SPANISH BANKING: 1985-1994
}

\author{
Joaquín Maudos, José Manuel Pastor and Javier Quesada
}

\begin{abstract}
Over the last decade, the Spanish banking sector has undergone a radical structural change. The old bank statu quo has broken down due both to the impact of technical change and to a strong deregulation process, that has given way to a much freer and competitive economic environment. Similarly, the rapid and intensive diffusion of new technologies on information has modified the banking industry in an important way.

The effect of these three phenomena (technical change, deregulation and increased competition) on production costs for the Spanish savings banks are the objectives of this study. We review three alternative econometric methods of approaching the impact of technical change.

Since we have available an incomplete data panel and with the aim of checking on the possibility that each firm has a particular level of efficiency -captured by the fixed effect-, we estimate the function using both techniques, pooling data and panel data. In other words, we estimate a mean costs function (OLS estimator) as well as a frontier costs function (panel data techniques).

We address the question of whether technical progress affects banks in a different way according to size and, finally, with the purpose of isolating our estimates of technical change from the evolution of financial costs and, therefore, of the role of competition and deregulation, we estimate a cost function using only operating costs. In this way we obtain a stricter measure of the impact of technical change.
\end{abstract}

KEY WORDS: Technical change, efficiency, banks. JEL: G21, O30.

\section{RESUMEN}

En la ultima década, el sector bancario español ha estado sometido a un radical cambio estructural. El viejo statu quo bancario se rompió debido al impacto del cambio técnico y al fuerte proceso desregulador. Adicionalmente, la rápida difusión de las nuevas tecnologías de la información ha modificado la industria bancaria de forma importante.

El objetivo de este estudio es analizar el efecto de estos tres fenómenos (cambio técnico, desregulación e incremento de la competencia) en los costes de producción de las cajas de ahorro españolas. Para ello se utilizan tres métodos econométricos alternativos para analizar el impacto del cambio técnico.

Ante la disponibilidad de datos de panel y con el objetivo de considerar la posibilidad de que cada empresa presente un nivel de eficiencia individual -recogido por el efecto fijo- se realizan las estimaciones considerando una función de costes media (estimador de $\mathrm{MCO}$ ) así como una función de costes frontera (mediante técnicas de panel).

Se analiza si el progreso técnico afecta a los bancos de manera diferente según su tamaño, finalmente, con el propósito de aislar las estimaciones del cambio técnico de la evolución de los costes financieros y, por tanto, de la competencia y desregulación, se estima una función de costes utilizando sólo los costes operativos. De esta forma se obtiene una medida más estricta del impacto del cambio técnico.

PALABRAS CLAVE: Cambio técnico, efficiencia, bancos.

JEL: G21, O30 


\section{INTRODUCTION}

Over the last decade, the Spanish banking sector has undergone a radical structural change. The old bank statu quo has broken down due both to the impact of technical change and to a strong deregulation process, that has given way to a much freer and competitive economic environment. Actually, the process of integration into a unique European Financial Market increased the role of product and price competition among banks. Such increase in competitiveness, made possible by a more liberalized regulatory framework, reached an intensive level throughout the whole period. Many private commercial and savings banks, without abandoning their own traditional role as financial intermediaries, started to compete among themselves to gain a share in the deposit and loan markets. More specifically, branch expansion was deregulated for private commercial banks in 1985; interest rate ceilings disappeared in 1987; investment coefficients that had freezed a very significant share of total assets in regulated loans and public debt were gradually eliminated; the ban on branch expansion for savings banks beyond their regional markets was lifted in 1989; the limitation for savings banks to perform specialized financial activities disappeared in the late eighties; and the coefficient on demand deposits was dramatically reduced in 1990. As a result, all kind of banks had to adopt a new strategy to survive under the new environment; to do so, they had additional instruments; branch expansion, pricing strategies, mergers and acquisitions, coordination policies, etc.

Similarly, the rapid and intensive diffusion of new technologies on information (computer engineering and telecommunication) has modified the banking industry in an important way. Thus, the application of these technologies has allowed banks to widen the type of products and services offered and it has served them to improve their organization and to lower some of the production and information costs.

However, the other side of the benefits brought about by the introduction of new technologies is their associated cost. Not all banks have been able to efficiently exploit the capabilities of new technologies in lowering total costs. Actually, it is argued that for some of the new technologies, there exists excess capacity that can explain in part a positive correlation between investment in technology and drops in productivity (the "productivity paradox"). Thus, at present time, costs related to new technologies are a very important component of operating costs, second only to labor costs. In fact, the last available information referred to 1993 indicates that, for the banking sector as a whole, technology costs amount to $33.6 \%$ of the total. 
The effect of these three phenomena (technical change, deregulation and increased competition) on production costs for the Spanish savings banks are the objectives of this study. For that purpose, we are using a panel including all savings banks (77 at the beginning and 51 at the end of the period) for the years 1985-94. Following Humphrey (1993), we review three alternative econometric methods of approaching the impact of technical change: first, the standard approach of introducing either a simple time trend or a technical indicator of technical change in the regression; second, the introduction of time dummies and, finally, the annual shift of the cross section cost function.

The paper is divided in 6 sections; section 2 contains some descriptive data on Spanish savings banks for the period under study; section 3 explains the different approaches to measuring the impact of technical change; section 4 contains empirical results; section 5 presents results by firm size; section 6 considers the impact of technical change on operating costs; finally, section 7 presents some concluding remarks.

\section{DESCRIPTIVE STATISTICS}

This section summarizes available empirical evidence on variables that are related to technical change. More precisely, figure 1 shows the evolution of total average costs throughout the period which is marked, in particular, by the evolution of interest costs, having operating costs a very stable trajectory. As a share of total assets, total average costs show a slightly decreasing pattern for the first four years of the decade (85-88), a period of five years of a positive trend (89-93), and a strong single drop for the final year of 1994. The dependency of average costs on their interest component makes monetary (and fiscal) policy clearly relevant in analyzing technical change.

By international standards, Spanish savings banks have always had very small branch offices and they still do as shown in figure 2 . The low number of employees per branch has remained fairly stable throughout the period, close to a value of 5.8, approximately one third of the average of other European banking systems. An interpretation for the small size of branches is the specialization of the Spanish savings banks in raising deposits, where they have gained an important fraction of market share to private commercial banks. An indicator of a positive trend in productivity appears in figure 3 where. in spite of branch expansion, (deflated) assets per 
branch grow at a steady rate throughout the period. This positive trend implies a more intensive use of fixed capital per unit of intermediated funds and should be reflected in a lower average cost.

Figure 1: Average Costs

(\% Assets)

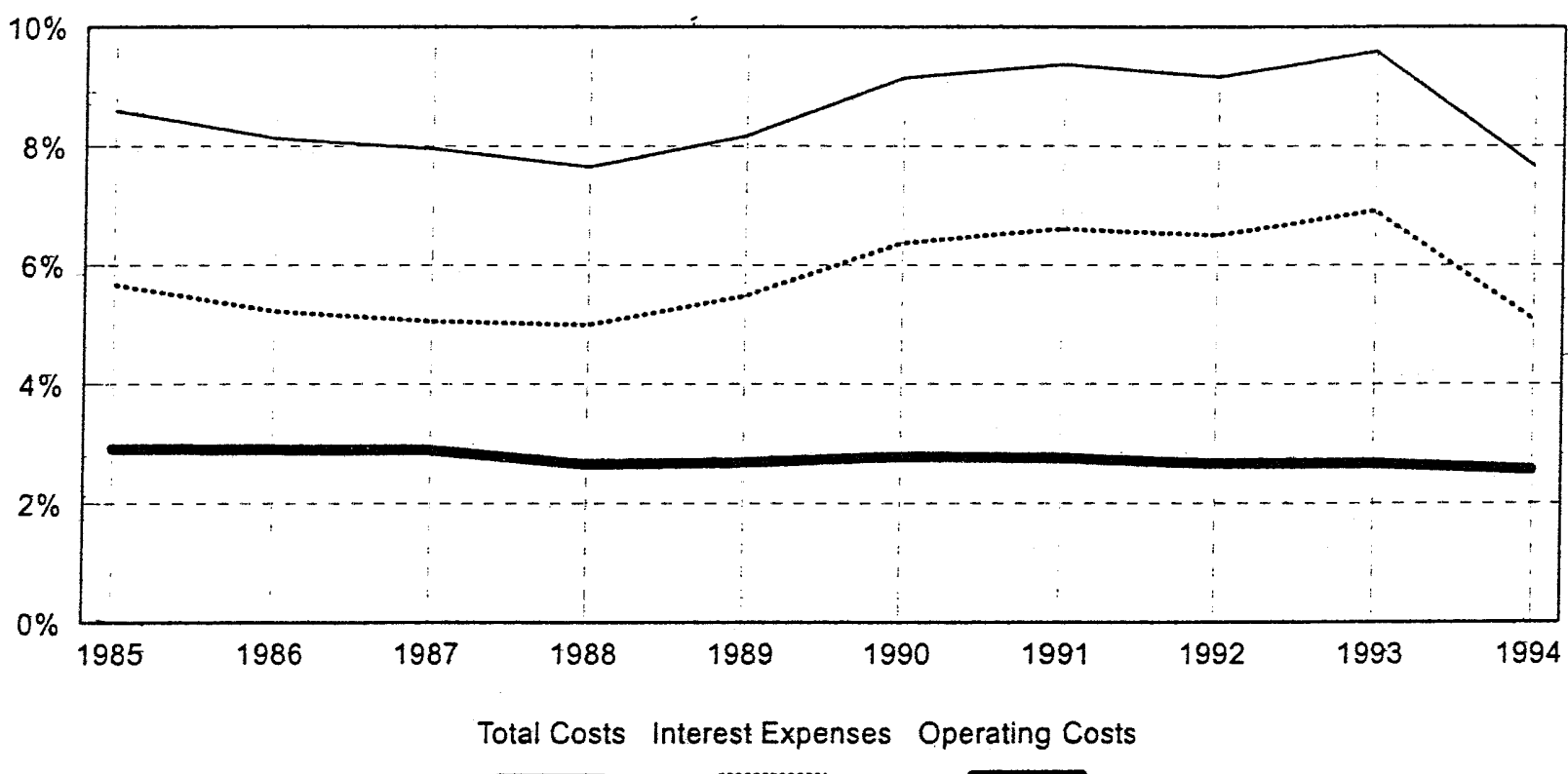

Source: CECA.

Figure 2: Employees per Branch

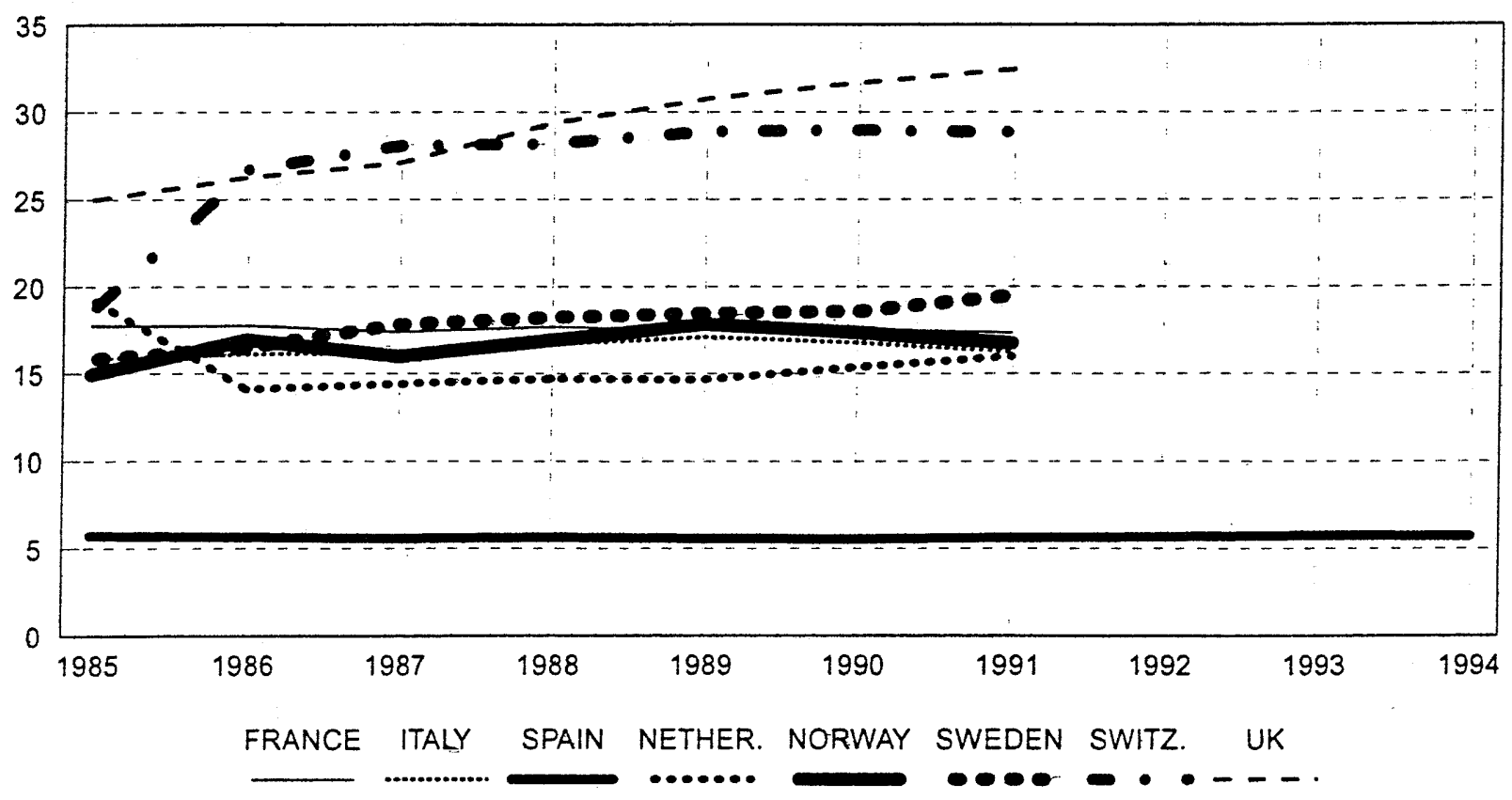

Source: CECA and Bank Profitability. 


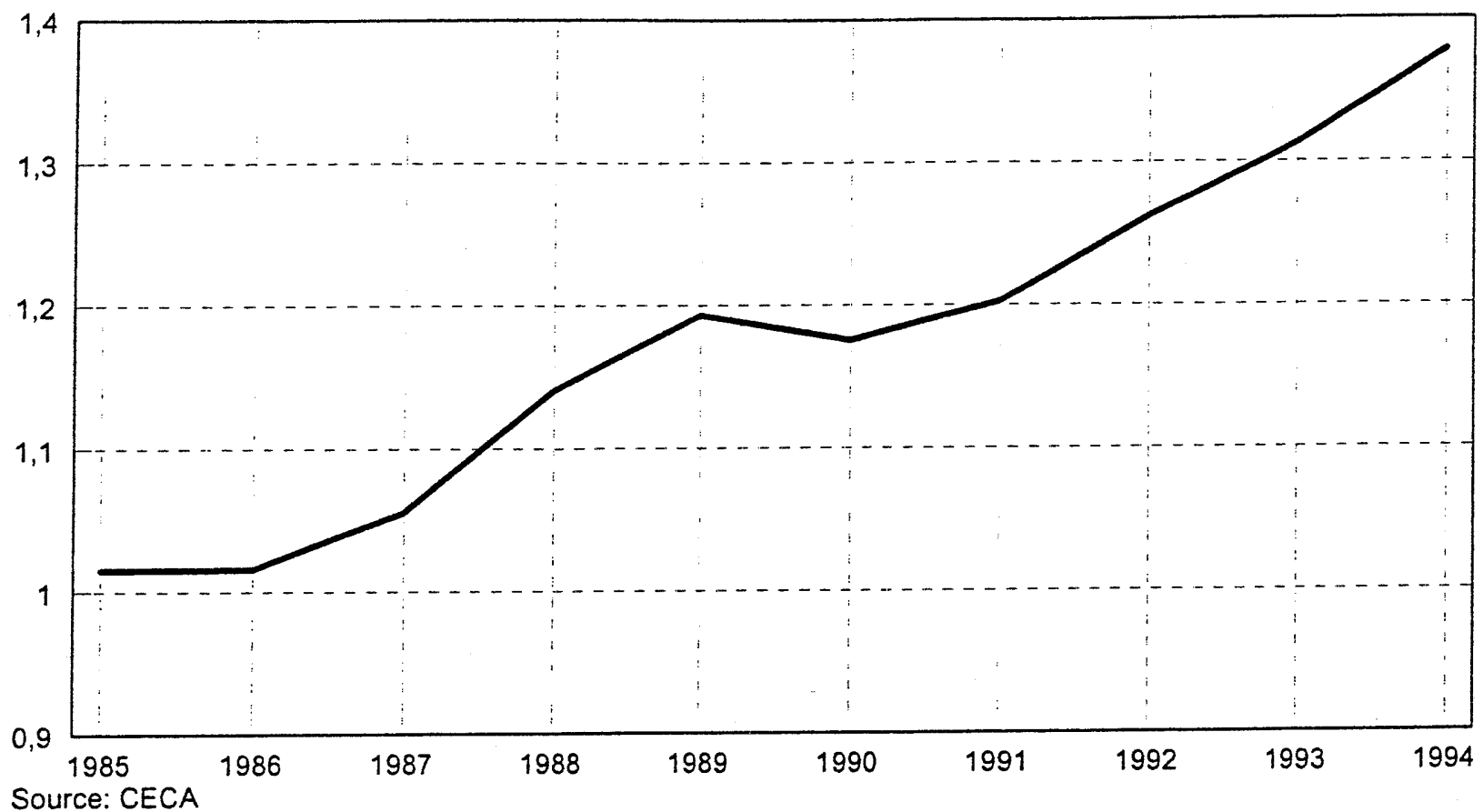

To check on the likely effect of firm size on average costs we split the sample by firms' size into six different groups. Figure 4 shows how large banks have lost their cost advantages they enjoyed at the beginning of the period. We also find a higher cost incurred by small banks, a spread that does not disappear throughout the whole period. For the remaining groups of banks of intermediate size we see a certain degree of convergence. As seen in figure 5, the behaviour of interest costs can explain that of total costs. Large banks have seen their interest cost increase dramatically after 1989 -when the deposit war started- until 1994, when interest costs fell significantly. Interestingly enough, the fall in interest costs for banks appears a year after market interest rates had experienced a large decrease, following the three devaluations of the national currency (September and November 1992 and May 1993) and the widening of the exchange rate spread to $+-15 \%$ at the EMS (August 1993). All other types of banks experienced a much less pronounced increase in interest costs and, interestingly enough, they converged to an almost identical share of total assets. This evidence can be interpreted as the reflection of an increase in interest rate competition for loanable funds that unified interest costs for banks of different sizes. 
Figure 4: Average Total Costs by Sizes

(\% Assets)

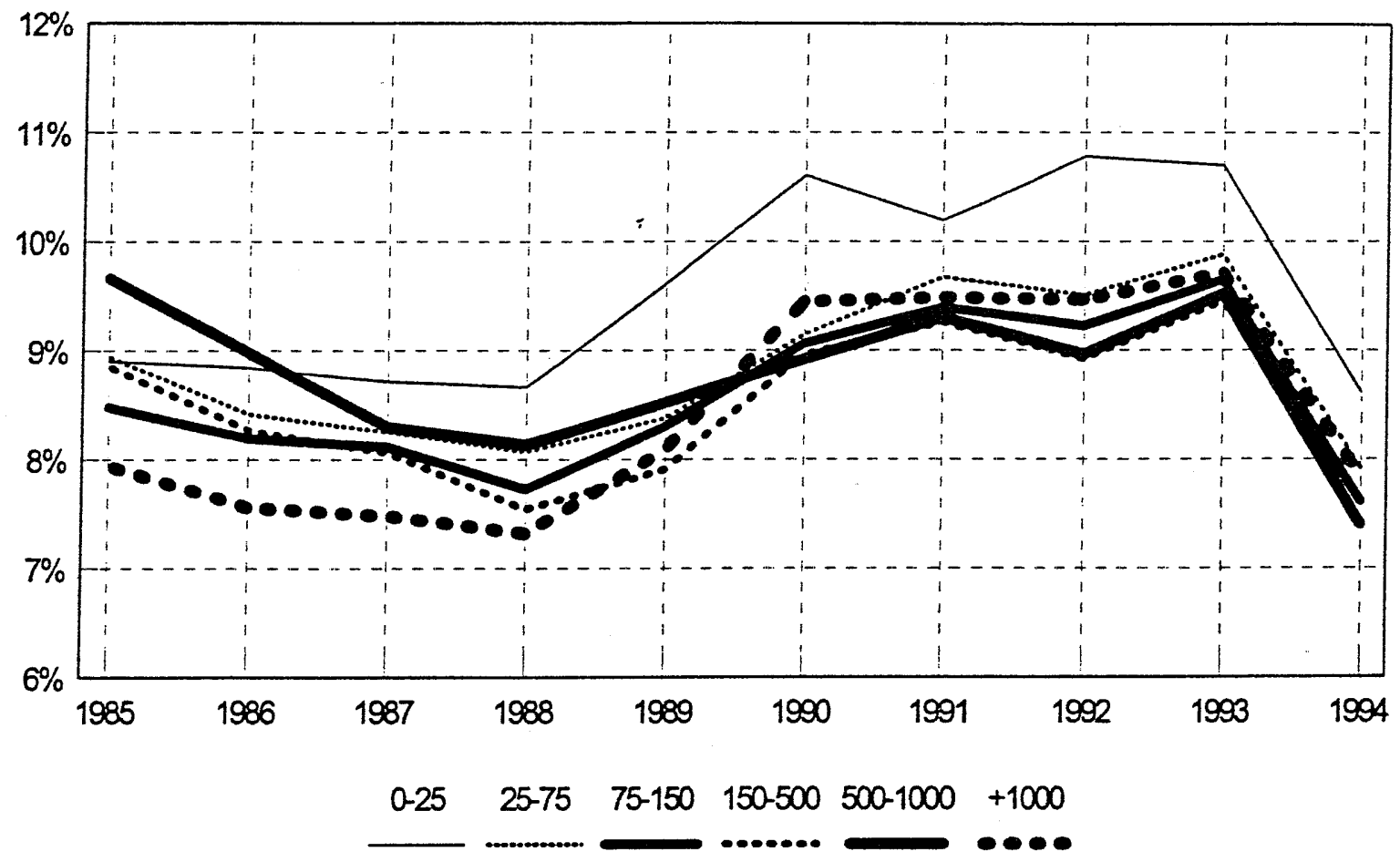

Sarœ: CECA.

Figure 5: Average Financial Costs by Sizes (\% Assets)

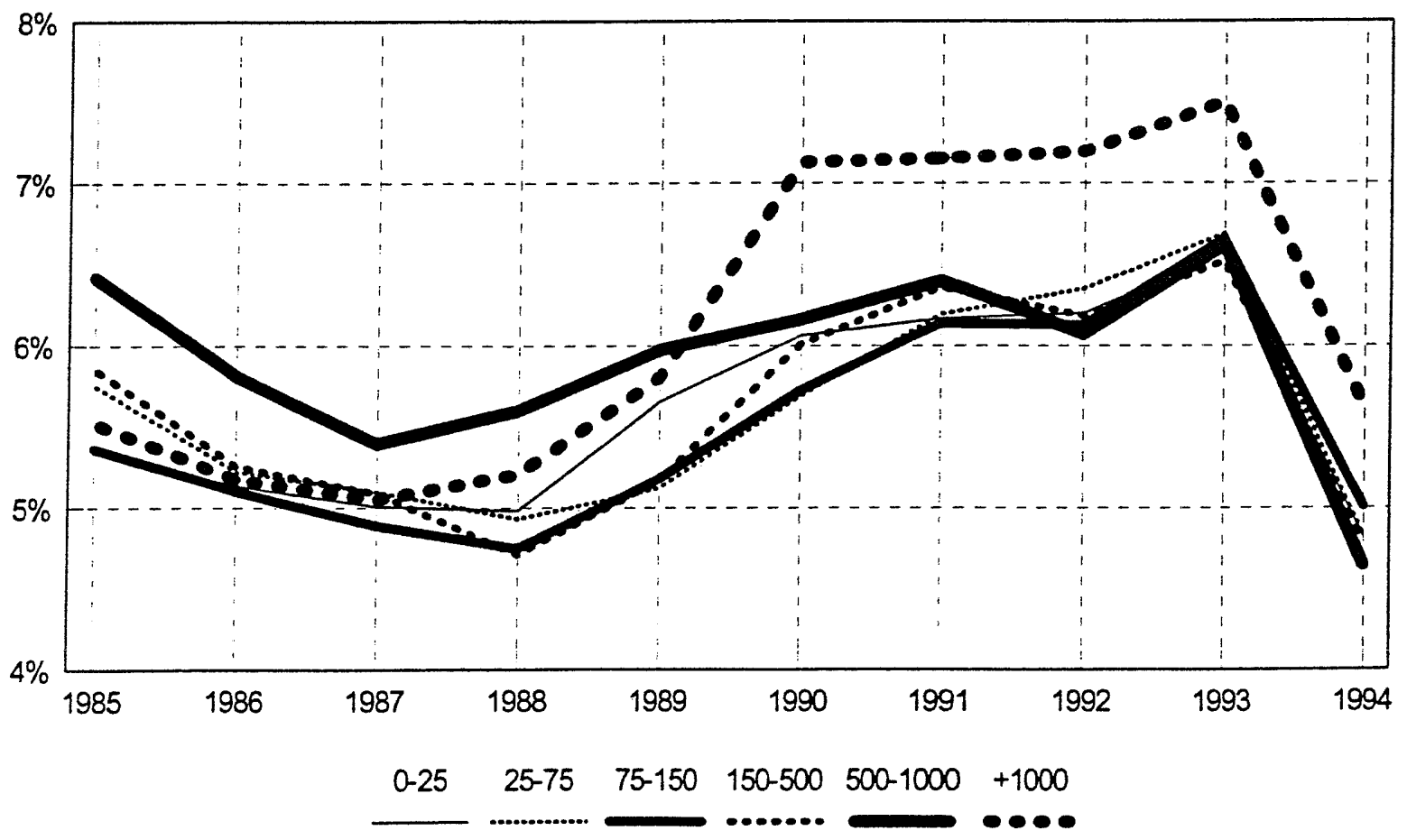

Source: CECA. 
The share of financial costs in total costs by bank size appears in figure 6 . The larger the bank the higher the share of interest cost. For the largest banks, this share amounts to $70 \%$, while for the smallest sized banks this share is close to $55 \%$. By contrast, operating costs as a share of total assets are lower the higher the size of the bank (see figure 7). Furthermore, the size of branches also differs by firm size as shown in figure $8^{1}$. We find the size of the branch -measured by assets- positively correlated with the size of the firm. More specifically, the average branch of the largest bank is three times as large as that of the smallest bank group. This relative difference is much smaller if we measure the size of branches by their number of employees (see figure 9), where we find much more homogeneous sizes of branches. With the exception of the second smallest group of banks we find for other sizes a clear reduction in the dispersion of the employment per branch.

Figure 6: Financial Costs / Total Costs

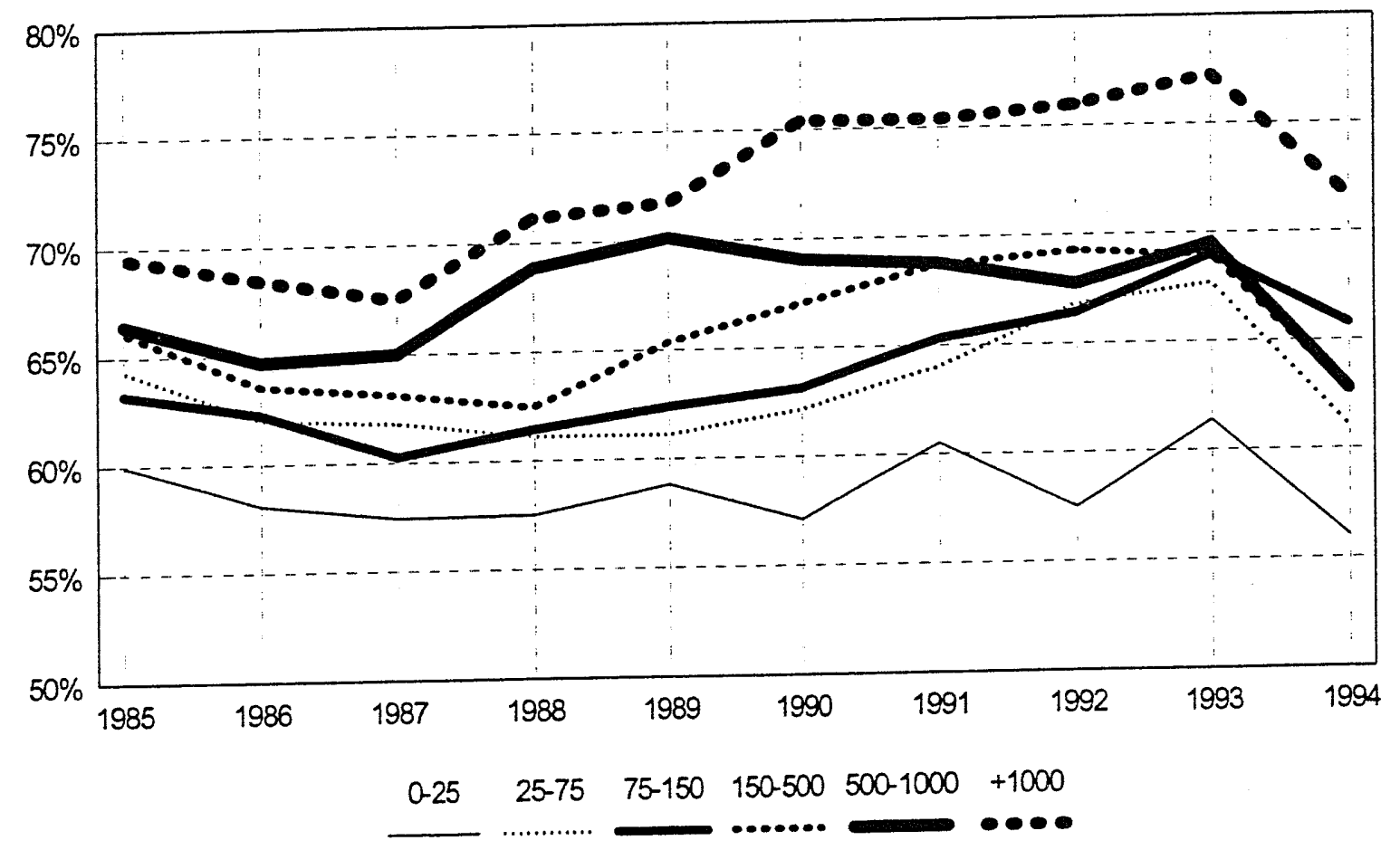

Source: CECA.

In figure 1 we observe a steady increase of the asset per branch ratio. However. figure 8 shows that for all bank groups such a relation is relatively stable. Both figures show that there has been a relative increase in the number of banks in the largest groups. 
Figure 7: Average Operating Costs by Sizes (\% Assets)

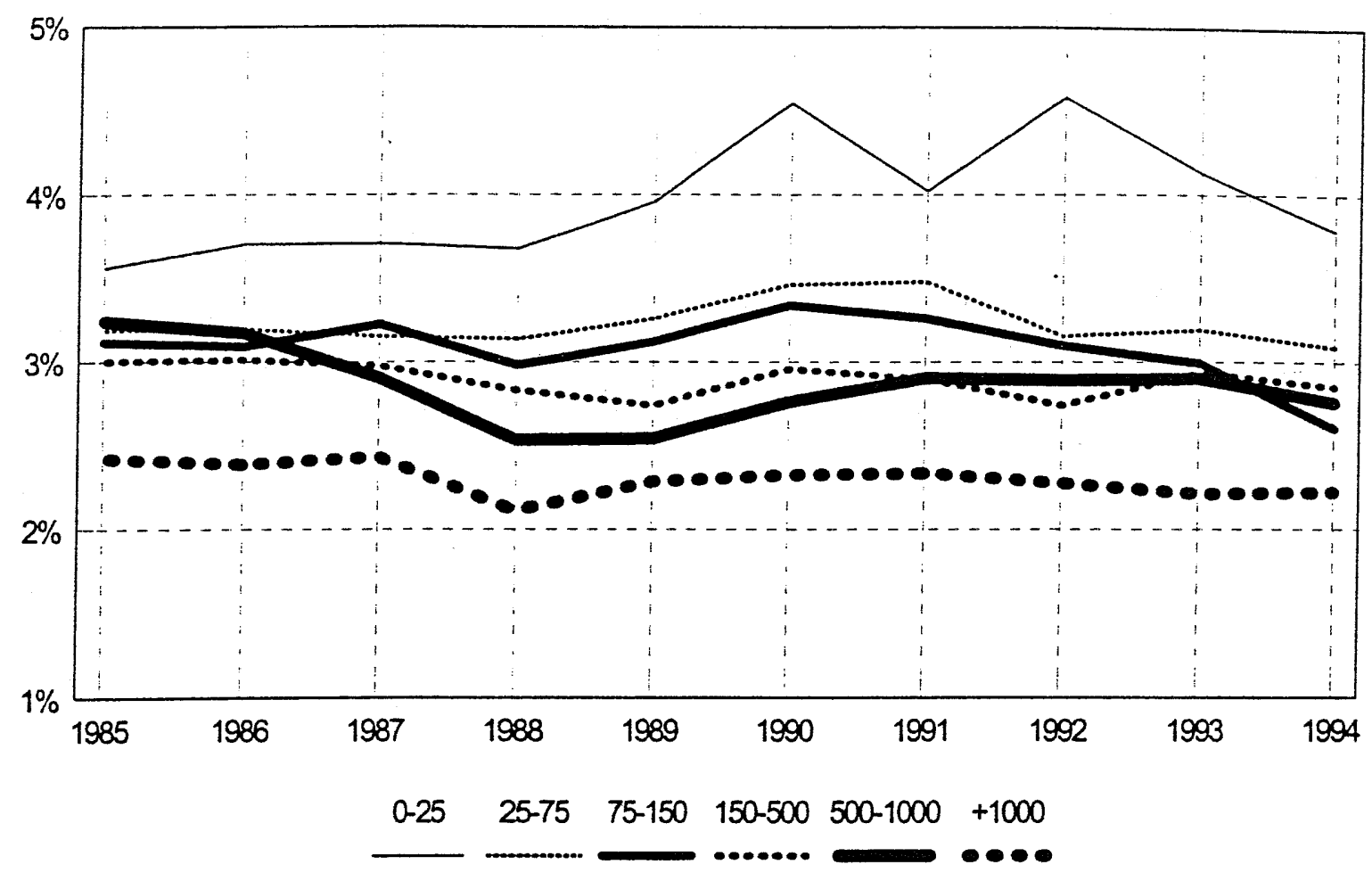

Sourc: CECA.

Figure 8: Assests by Branch

(Millions)

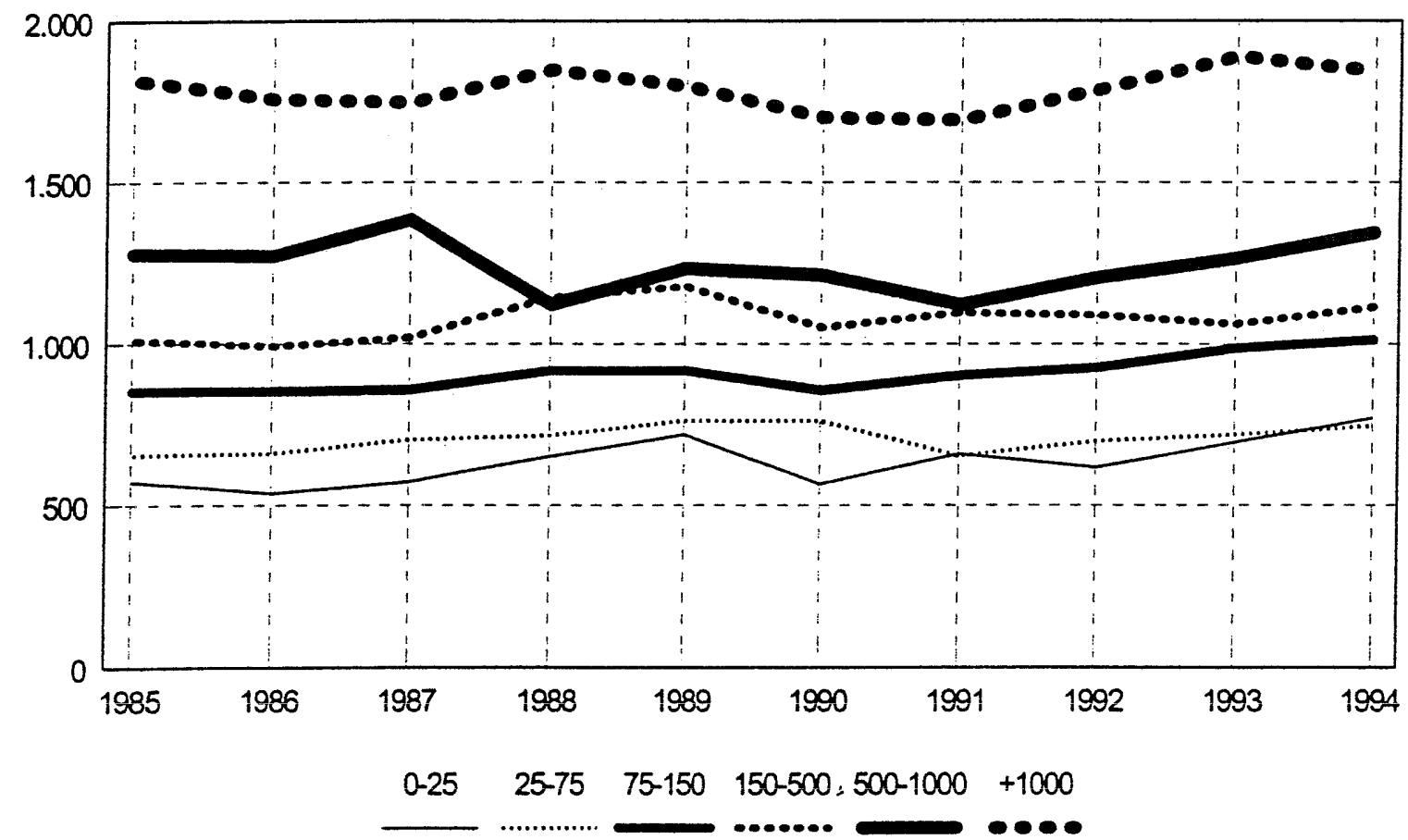

Source: CECA 
Figure 9: Number of Employees per Branch (by sizes)

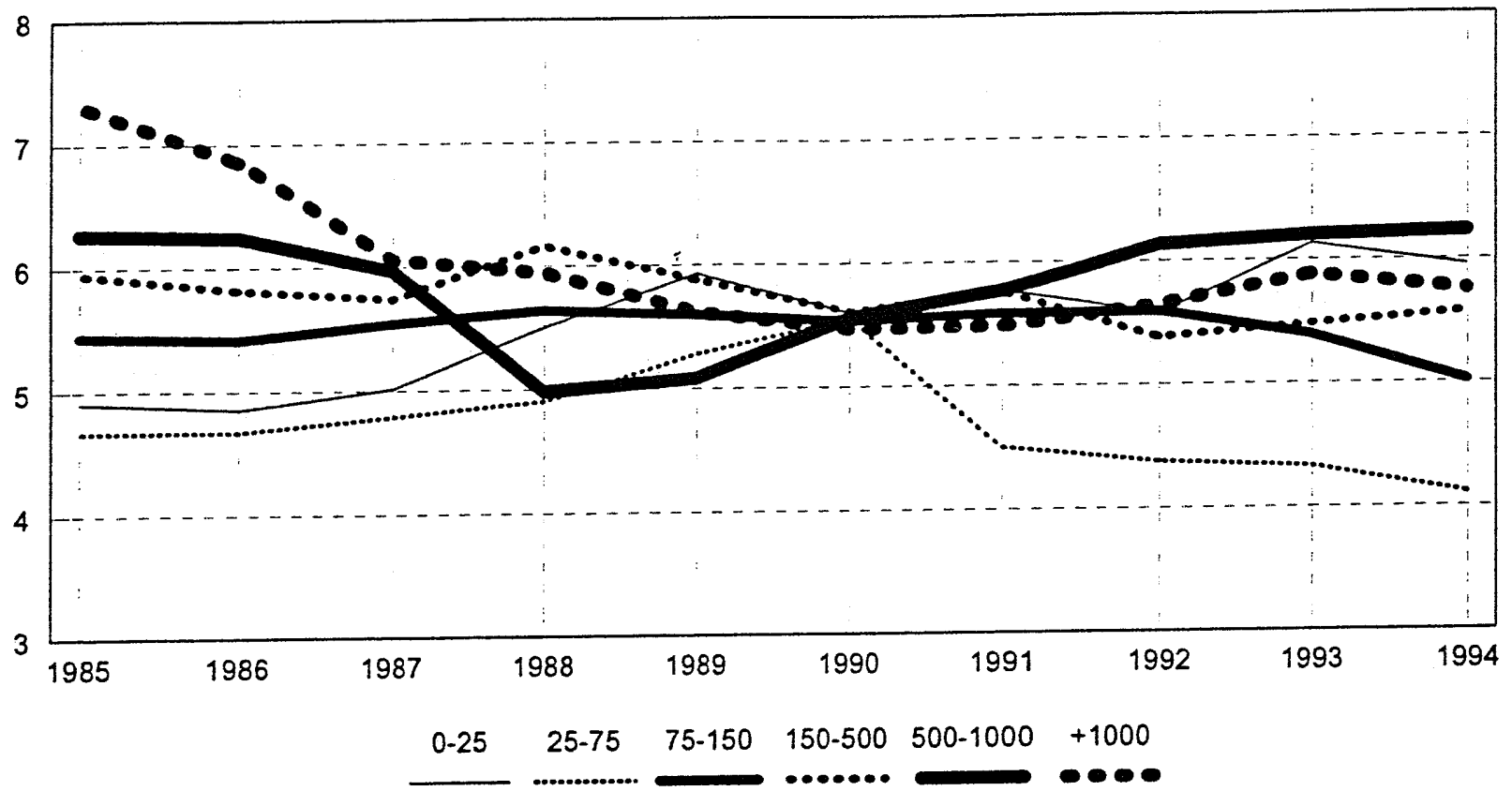

Source: CECA.

\section{MEASURING THE IMPACT OF TECHNICAL CHANGE}

In this study, we analyze the impact of technical progress using three different approaches. The first approach introduces a given measure of technical change into the cost equation and check for the estimated parameters. To measure technical change we use, in turn, four different indicators, a time trend that assumes a constant rate of technical progress, and three other technical indicators; namely, an index based on the aggregate number of ATMs, an index based on the number of cash and credit cards issued by all savings banks, and an average combining these last two indexes.

Although it is frequent to use technological indexes as proxy variables of the technical change, in the Spanish banking sector, the lack of information on the effects of these productprocess innovations on the production costs, does not allow us to justify the technological indexes as being indicators of cost-saving innovation. For that reason, we use three different technological indexes as well as other approaches to check the robustness of the results. 
As opposed to the simple time trend, technology indicators show a lower and unsteady rate of increase, as shown in figure 10. The time trend is shown by the line labelled (A). Lines (B), (C) and (D) show the indexes corresponding to the diffusion of technical innovations, ATMs, cash and credit cards and their combined index. These indicators show a slightly increasing rate for the first part of the decade and a slightly decreasing one for the rest of the period. As a result of this, the different intensity at which technical progress takes place is recognized.

Figure 10: "Technological" Indicators

of Technical Change

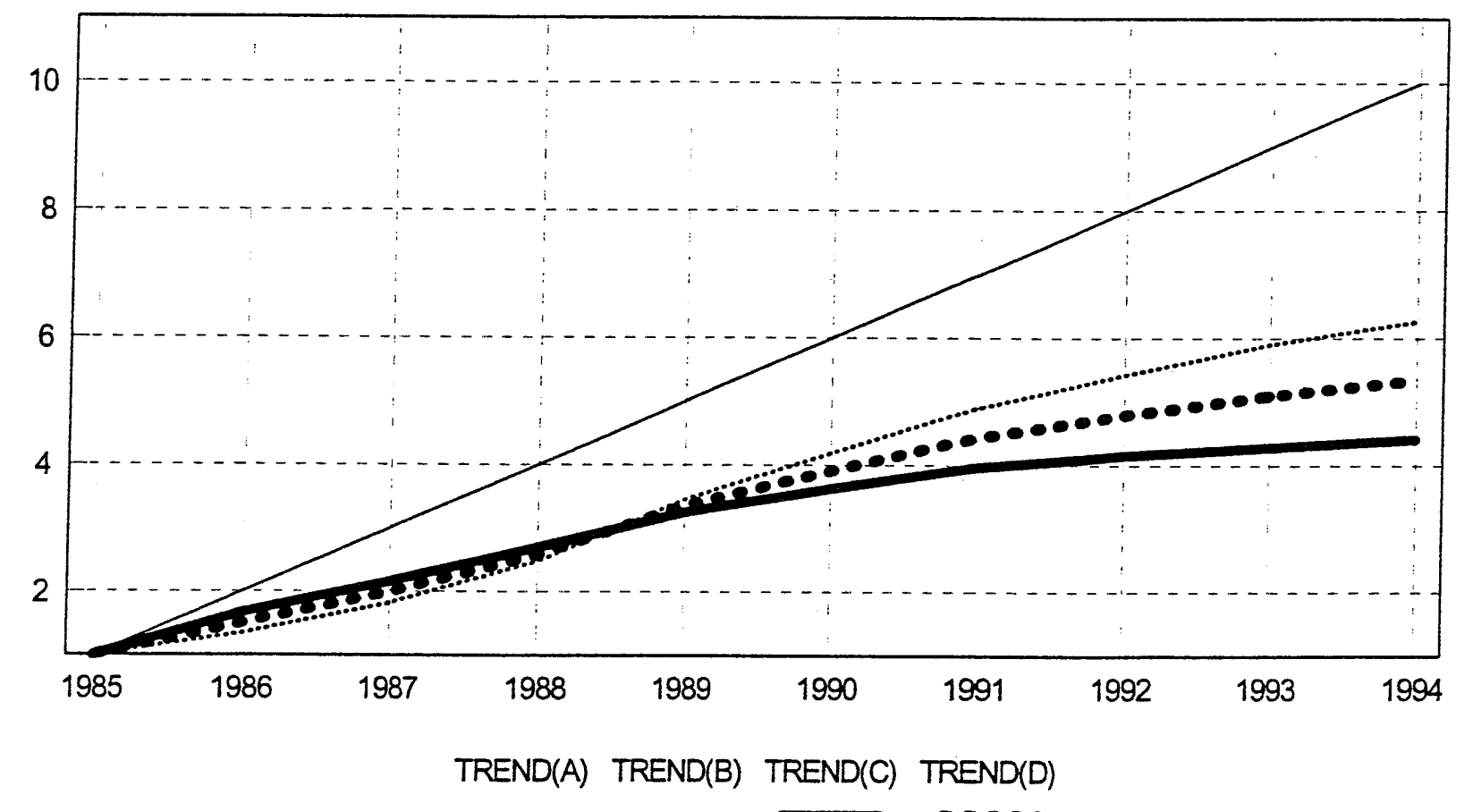

Source: CECA.

The different levels of trend (B) and (C) before and after 1989 are the reflection of the distinct behavior of the rates of growth of ATMs and cash and credit cards after that year. Thus, what is shown in figure 10 for the period after 1989 is a decreasing trend in the number of cards per ATM.

The second approach to evaluate the impact of technical change makes use of time dummies. With the estimated parameters, an index of technical change for each year is computed. This approach provides more flexibility than the introduction of a constant time trend because it allows for a non-constant rate of growth of technical progress. 
The third and last method used to measure the impact of technical progress consists in the evaluation of yearly shifts in the estimated cross-section cost functions. This approach is quite flexible because the parameters of the translog cost function are reestimated in every annual regression.

Since we have available an incomplete data panel and with the aim of checking on the possibility that each firm has a particular level of efficiency -captured by the firm-specific effect-, we estimate the function using both techniques, pooling data and panel data. In other words, when using panel data techniques, we estimate a frontier costs function rather than a mean costs function ${ }^{2}$.

Equation (1) shows the general form of the second order translog cost function to be estimated ${ }^{3}$. We include two types of outputs, and three input prices.

$$
\begin{gathered}
\operatorname{LnTC}=\alpha_{0}+\sum_{i=1}^{2} \alpha_{i} \operatorname{Ln} Q_{i}+1 / 2 \sum_{i=1}^{2} \sum_{j=1}^{2} \alpha_{i j} \operatorname{Ln} Q_{i} Q_{j}+\sum_{m=1}^{3} \beta_{m} \operatorname{Ln} P_{m}+ \\
1 / 2 \sum_{m=1}^{3} \sum_{n=1}^{3} \beta_{m n} \operatorname{Ln} P_{m} \operatorname{Ln} P_{n}+\sum_{i=1}^{2} \sum_{m=1}^{3} \lambda_{i m} \operatorname{Ln} P_{m} \operatorname{Ln} Q_{i}+\Psi_{0} T(.)+ \\
1 / 2 \Psi_{00} T(.)^{2}+\sum_{i=1}^{2} \psi_{i} T(.) \operatorname{Ln} Q_{i}+\sum_{m=1}^{3} \gamma_{m} T(.) \operatorname{Ln} P_{m}+\epsilon
\end{gathered}
$$

where $T C$ are real total production costs, $Q_{\mathrm{i}}$ are the components of the production vector (i=1: borrowed funds in real terms, $\mathrm{i}=2$ : loans in real term), $P_{\mathrm{m}}$ are real input prices $(\mathrm{m}=1$ : labor, $\mathrm{m}=2$ : borrowed funds, and $\mathrm{m}=3$ : physical capital), $T(\cdot)$ is an indicator of technical change, where $T(A)$ is a simple time trend dummy variable, $T(B)$ is an index based on the number of ATMs, $T(C)$ is an index based on the number of cards issued, and $T(D)$ is an indicator combining cards and ATMs.

To estimate the impact of technical change we calculate the variation in the average cost due to a given change in technology. This effect can be measured by the partial derivative of the

${ }^{2}$ See in Green (1993) a review of different econometric approaches to efficiency measurement.

"We estimate (equation 1) imposing the usual restrictions of symmetry and homogeneity of degree one in prices. 
estimated average cost with respect to the used indicator of technical progress. Equation (2) contains this expression.

$$
\operatorname{TREND(.)}=\frac{\partial \operatorname{Ln} T C}{\partial T(.)}=\phi_{0}+\Psi_{00} T(.)+\sum_{i=1}^{2} \psi_{i} \operatorname{Ln} Q_{i}+\sum_{m=1}^{3} \gamma_{m} \operatorname{Ln} P_{m}
$$

The first two terms on the right hand side capture the pure effect of technical change, that is the decrease in costs, keeping constant inputs's proportions. The third term measures the technical change associated with changes in output (scale augmenting technical change). Finally, the fourth term is a measure of the technical change associated with the change in the use of inputs due to changes in input prices.

A more flexible approach is to permit a non-constant rate of technical change -through the introduction of time dummies- in such a way that non-constant annual variations can be computed ${ }^{4}$. Furthermore, this specification permits us to capture the neutral technical change, the scale-augmentative technical change (through the interaction of temporary and output effects) and the non-neutral technical change (through the interaction of prices). However, after the poor initial empirical estimates obtained for a highly broad specification, we chose a functional form that only included neutral technical change. The particular translog function that was estimated was the following:

$$
\begin{aligned}
\operatorname{LnTC}= & \sum_{t}^{10} n_{t} D T_{t}+\sum_{i=1}^{2} \alpha_{i} \operatorname{Ln} Q_{i}+1 / 2 \sum_{i=1}^{2} \sum_{j=1}^{2} \alpha_{i j} \operatorname{Ln} Q_{i} Q_{j}+\sum_{m=1}^{3} \beta_{m} \operatorname{Ln} P_{m}+ \\
& 1 / 2 \sum_{m=1}^{3} \sum_{n=1}^{3} \beta_{m n} \operatorname{Ln} P_{m} \operatorname{Ln} P_{n}+\sum_{i=1}^{2} \sum_{m=1}^{3} \lambda_{i m} \operatorname{Ln} P_{m} \operatorname{Ln} Q_{i}+\epsilon
\end{aligned}
$$

According to this approach, the growth rate in technical change was expressed as the difference of two time dummies:

$$
I N D E X=n_{t+1}-n_{t}
$$

\footnotetext{
${ }^{4}$ See Caves. Christensen and Swanson (1981) and Baltagi and Griffin (1988).
} 
When sufficient observations are available, it is possible to evaluate technical change in a more flexible way than that of temporary effects. The procedure implies the estimation of a different cost function per period. Thus, whereas in the model of temporary effects technical change affects the cost function through an annual homothetic shift, this alternative approach allows for all parameters to be influenced by technical change. This model is equivalent to the former one after eliminating the temporary effects and estimating the equation for each year in the sample 5 .

In this procedure, the growth rate of technical change is the change in average cost that would be derived if a bank used at time $t$ the technology available one period later.

$$
\operatorname{SHIFT}=\frac{\left(A \hat{C}^{*}{ }_{t+1}-A \hat{C}_{t}\right)}{A \hat{C}_{t}}
$$

where:

- $A \hat{C}^{*}{ }_{t+1}=\exp \left(\beta_{t+1}\left(X_{t}\right)\right) / T A_{t} \quad$ is the predicted average cost per asset in period $t$ using the technology available in period $t+1$;

- $A \hat{C}_{t}=\exp \left(\beta_{t}\left(X_{t}\right)\right) / T A_{t}$ is the predicted average cost per asset in period $t$;

- $\beta_{t}$ is the estimated parameter of the cost function for period $t$

- $X_{t}$ are data values corresponding to period $t$;

- $T A_{t}$ are total assets for period $t$

\footnotetext{
s See Humphrey (1993).
} 


\section{THE EFFECTS OF TECHNICAL CHANGE: EMPIRICAL RESULTS}

Our sample is formed by all Spanish savings banks and extends over the period 1985-94. A merged institution is treated as a different bank from the institutions that existed before the merging process ${ }^{6}$. The number of existing institutions has dropped from an initial value of 77 to 51 , and the total number of observations is 659 . Data sources are the savings banks association CECA, and the National Bureau of Statistics, INE. Nominal variables (costs, loans and borrowed funds, and input prices) have been transformed in real terms using the GNP deflator.

Table 1, and figures 11-12 report the results of computing equation (2) after the estimation of equation (1). Pooling data (mean costs function) and panel techniques (frontier costs function) were used in the regressions?. Time trend (labelled A) shows a positive continuous rate of growth of technological change over the whole period, that can be interpreted as a continuously decreasing trend on average costs. For pooled regressions (see figure 11), this accumulated reduction in average costs amounts approximately to $10 \%$ for the ten year period, at firm level. If we replace the time trend by any of the three alternative indicators of technical change ( $B, C$ and $D$ ), we find a larger effect of technical change on average costs -of approximately $15 \%$, that is particularly strong in the case of indicator $(\mathrm{C})$, the plastic cards index.

Figure 12 shows the accumulated index of technical change using panel data estimation techniques. As it is well known, these techniques introduce in the regression a different constant term for each firm in the sample, that can be interpreted as a measurement of firm efficiency. Two results are worth mentioning. First, the accumulated impact of technical change on total costs is significantly lowered to a level of $5 \%$. Second, the different effects derived from using distinct indicators are much more alike than before.

${ }^{6}$ In this study we do not consolidate backwards merged institutions creating fictitious banks. If two institutions merged into a new one they disappear from then on and a new bank is born.

${ }^{7}$ The reported results are referred to the fixed effects model because according to the Hausman test it is not possible to accept the hypothesis of absence of correlation between the individual effects (inefficiency terms) and the regressors, being in that case inconsistent the GLS estimator (random effects model). 


\begin{tabular}{|c|c|c|c|c|c|c|c|c|}
\hline \multirow[b]{2}{*}{ Year } & \multicolumn{4}{|c|}{ Pooling Data Estimation } & \multicolumn{4}{|c|}{ Fixed Effects .Model Estimation } \\
\hline & $\operatorname{Trend}(A)$ & Trend( $B)$ & Trend(C) & Trend(D) & Trend(A) & Trend(B) & Trend $(C)$ & Trend(D) \\
\hline 1985 & $-0.0204^{* * *}$ & $-0.0204^{* * *}$ & $-0.0204^{* * *}$ & $-0.0204^{* * *}$ & $-0.0093 * * *$ & $-0.0093 * * *$ & $-0.0093 * * *$ & $-0.0093 * * *$ \\
\hline 1986 & $-0.0189^{* * *}$ & $-0.0205^{* * *}$ & $-0.0197^{* * *}$ & $-0.0200^{* * *}$ & $-0.0096^{* * *}$ & $-0.0103 * * *$ & $-0.0099 * * *$ & $-0.0101^{* * *}$ \\
\hline 1987 & $-0.0179 * * *$ & $-0.0208 * * *$ & $-0.0195 * * *$ & $-0.0204^{* * *}$ & $-0.0097 * * *$ & $-0.0109^{* * *}$ & $-0.0106^{* * * *}$ & $-0.0107 * * *$ \\
\hline 1988 & $-0.0168^{* * *}$ & $-0.0205^{* * *}$ & $-0.0199^{* * *}$ & $-0.0202^{* * *}$ & $-0.0091^{* * *}$ & $-0.0106^{* * *}$ & $-0.0104^{* * *}$ & $-0.0105^{* * *}$ \\
\hline 1989 & $-0.0144 * * *$ & $-0.0181^{* * *}$ & $-0.0186^{* * *}$ & $-0.0184^{* * *}$ & $-0.0077^{* * *}$ & $-0.0093^{* * *}$ & $-0.0095^{* * *}$ & $-0.0094^{* * *}$ \\
\hline 1990 & $-0.0129 * * *$ & $-0.0172^{* * *}$ & $-0.0186^{* * *}$ & $-0.0179^{* * *}$ & $-0.0051^{* * *}$ & $-0.0069^{* * *}$ & $-0.0075^{* * *}$ & $-0.0072 * * *$ \\
\hline 1991 & $-0.0108^{* * *}$ & $-0.0158^{* * *}$ & $-0.0181^{* * *}$ & $-0.0169^{* * *}$ & $-0.0032^{* *}$ & $-0.0053^{* * *}$ & $-0.0063^{* * *}$ & $-0.0058^{* * *}$ \\
\hline 1992 & $-0.0075^{* * *}$ & $-0.0137^{* * *}$ & $-0.0167^{* * *}$ & $-0.0152^{* * *}$ & $-0.0028^{*}$ & $-0.0054^{* * *}$ & $-0.0067^{* * *}$ & $-0.0061^{* * *}$ \\
\hline 1993 & $-0.0050^{*}$ & $-0.0124 * * *$ & $-0.0163^{* * *}$ & $-0.0143^{* * *}$ & -0.0012 & $-0.0044^{* * *}$ & $-0.0060^{* * *}$ & $-0.0052^{* * *}$ \\
\hline 1994 & -0.0011 & $-0.0101^{* * *}$ & $-0.0145^{* * *}$ & $-0.0123^{* * *}$ & -0.0052 & $-0.0090^{* * *}$ & $-0.0105^{* * * *}$ & $-0.0100 * * *$ \\
\hline $\begin{array}{c}\text { Average } \\
\text { annual rate } \\
1985-1994\end{array}$ & $-0.0135^{* \star \star}$ & $-0.0175^{\star \star *}$ & $-0.0185^{\star \star \star}$ & $-0.0189 * * *$ & $-0.0068^{* \star *}$ & $-0.0085^{\star \star \star}$ & 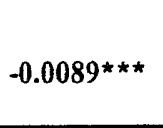 & $-0.0087^{\star \star \star \star}$ \\
\hline
\end{tabular}

*** Significant at the $1 \%$ level

** Significant at the $5 \%$ level

* Significant at the $10 \%$ level

Figure 11: Time Trend and Technological Indicators of Technical Change (Pooling Data Estimation)

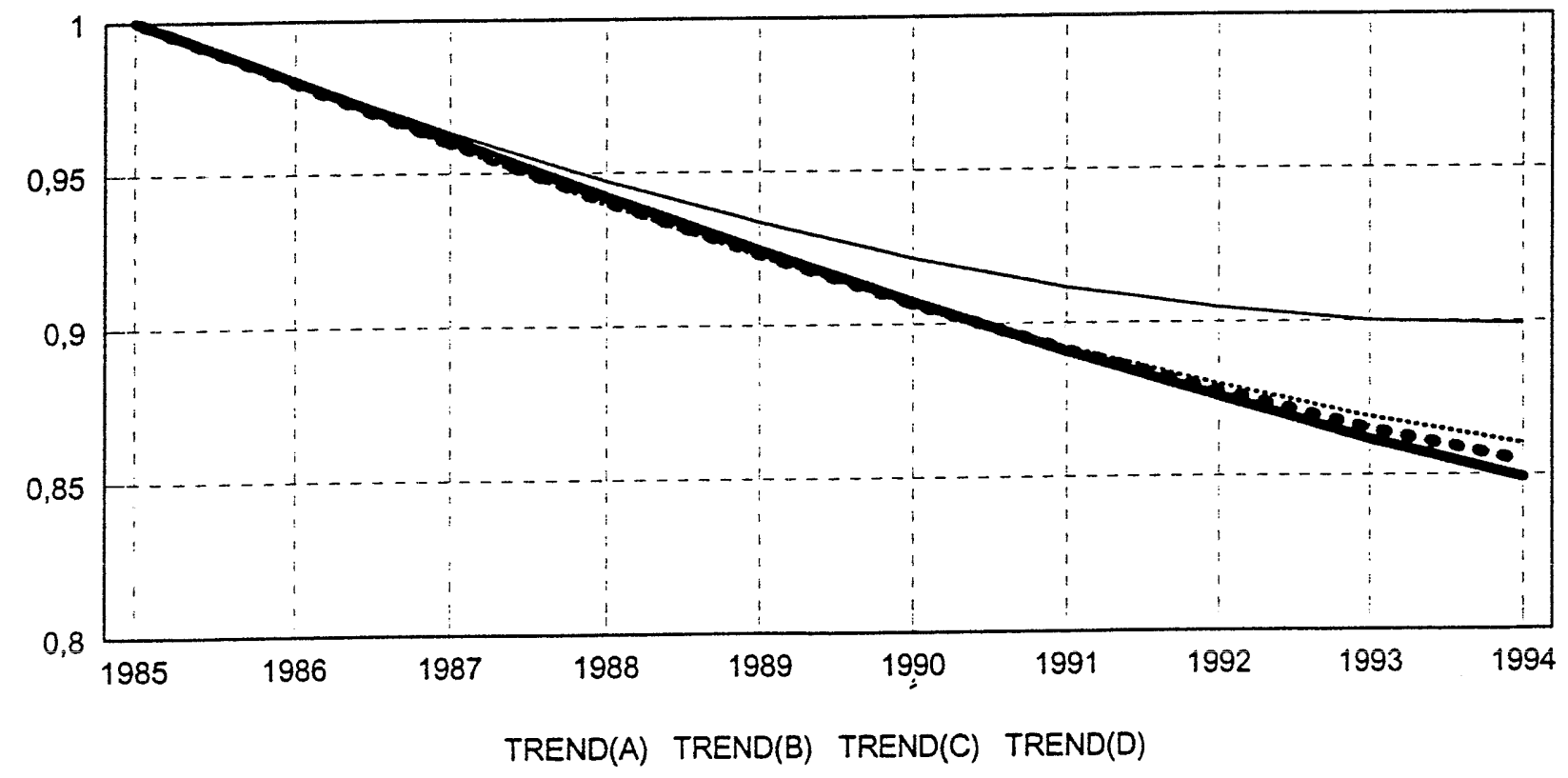

Source: See text. 
Figure 12: Time Trend and Technological Indicators of Technical Change (Panel Data Estimation)

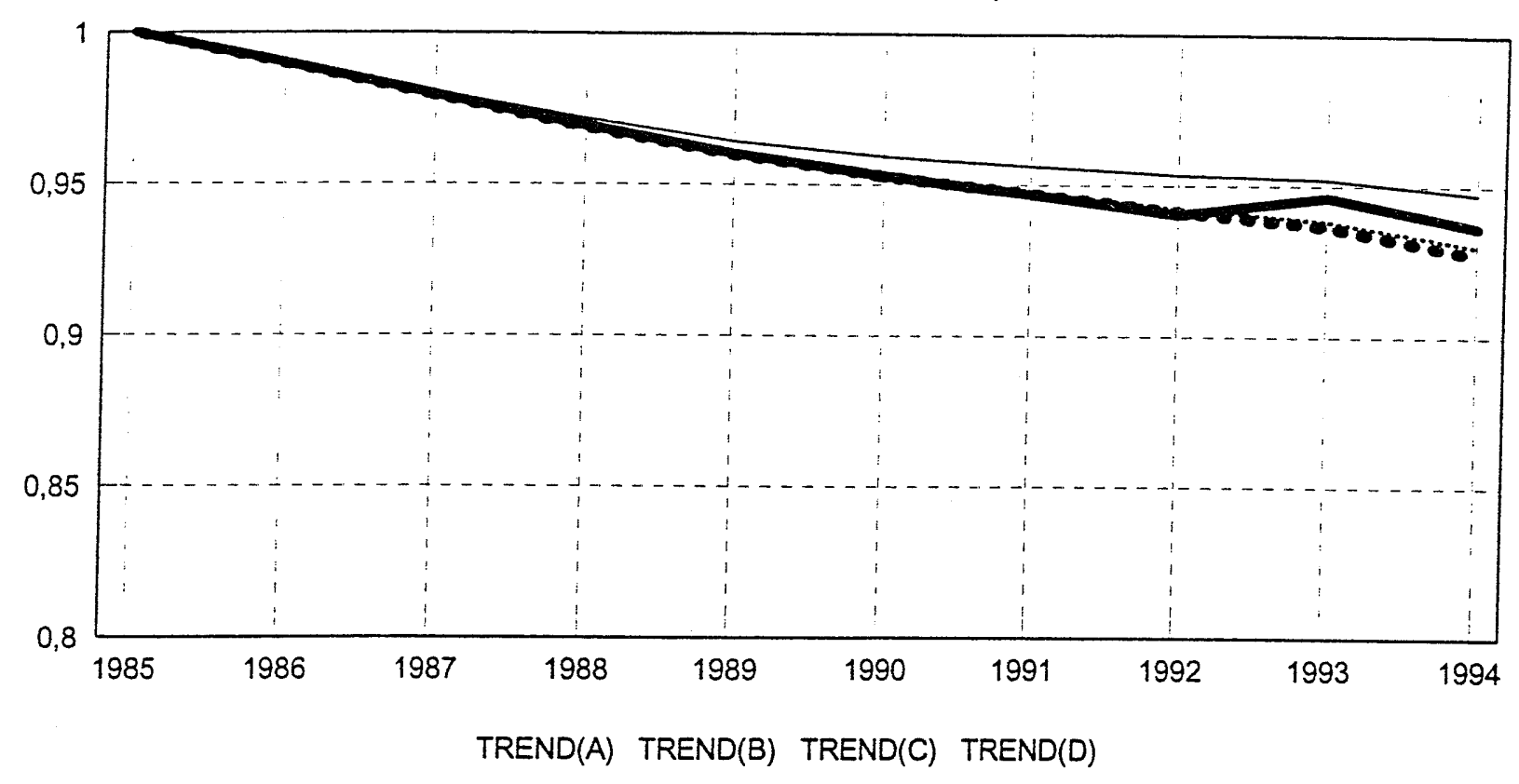

Source: See text.

The difference in the estimated impact of technical progress derived from pooling data or from a model with fixed effects, can be as high as fifty per cent. Such a difference can be interpreted as evidence in favor of introducing individual effects that capture the influence of unobservable characteristics of each firm in the sample, that we attribute to differences in their levels of efficiency. As we mentioned before, when using panel date techniques, we estimate a frontier rather than a mean costs function.

The results of table 1 show that, in general, technical progress is reduced throughout the period with the exception of the last year. Furthermore, in the case of trend (A), the estimated values are not statistically different from zero for the last years of the period.

The results obtained with the fixed effects model with the standard time trend approach, are similar to those obtained by Maudos (1994) ${ }^{8}$. More precisely, this author finds for the Spanish savings banks a significant technical progress of -0.5 per year.

${ }^{8}$ In this paper, using the same technique, a third order translog cost function is estimated for the period 1988-1991. 
A second method to evaluate the impact of technical change implies the use of time dummies -one per year-in our estimating process. With this method, we do not impose a constant rate of change in average cost. In fact, the estimated parameter associated to each dummy variable measures the variation in average costs that is not explained by other explanatory variables and that is attributable to the technical change experienced during that period.

Table 2 contains the results. The outcomes that we get correspond quite closely with the behavior of average total costs that was shown in figure 1. Thus, we can observe that there exists statistically significant technical progress (fall in average costs) over the periods 1985-88, 199192 and 1993-94, whereas there is technical regress (increase in average costs) in the years 198890, and 1992-93, although not statistically significant except the period 1989-90. On the other hand, the average annual rate of technical progress is relatively similar to that obtained with the time trend approach.

The third method to evaluate the impact of technical change is the shift method. This approach constitutes a more flexible way to measure technical change. It allows for the change of all cost function parameters and is based on the annual estimation of a cost function. If we compare the results obtained from using this method (table 3) with those obtained in pooling data estimation, the impact of technical change behaves in a way very similar to that found with the time dummies approach, namely a positive technical progress. However, the accumulated level exceeds that of the time dummies approach and is smaller than the value obtained with the method based on a time trend. By contrast, in panel data estimations the accumulated level of the index of technical change exceeds that of the other two approaches. Furthermore, the annual behavior is much more irregular than that derived with other methods. This is the natural consequence of the larger degree of flexibility of this last approach. Figures 13-14 present a summary of the accumulated indexes measuring the impact of technical change computed making use of the three different approaches and the two different ways of running the regressions, pooling data or panel techniques.

These results are similar to those obtained by Pastor (1995). This author, using a nonparametric frontier approach with Malmquist indexes, finds technical progress for the periods 1986-88 and 1990-92, and technical regress for the period 1989-90. 


\begin{tabular}{|c|c|c|}
\hline \multicolumn{3}{|c|}{$\begin{array}{c}\text { TABLE } 2 \\
\text { Tme dummies approach to technical change }\end{array}$} \\
\hline MER & Pooling Data & Fued CWects \\
\hline $1985-1986$ & .0018 \%*** & .40063 \\
\hline $1986-198 \%$ & $-0.0252 * * *$ & $00153^{* * *}$ \\
\hline $1987-1988$ & $0,0136^{*} * *$ & $-0.0184 * *$ \\
\hline $1988-1989$ & $0.0187 * * * *$ & 0.0051 \\
\hline 1989.1990 & $0.0322^{*}$ & $00129 * *$ \\
\hline $1990 \cdot 1991$ & .00103 & $-010148 * *$ \\
\hline 1991.1993 & $.00154 *$ & $-0,000 \%$ \\
\hline $1992+1993$ & $00163^{\circ}$ & 0,0057 \\
\hline $1993-1994$ & $.0 .0740^{* * * *}$ & $-0.0241 * * *$ \\
\hline $\begin{array}{c}\text { Average } \\
\text { annual rate } \\
1985-1994\end{array}$ & $-0.0111 \%$ & -0.0064 **** \\
\hline
\end{tabular}

\begin{tabular}{|c|c|}
\hline \multicolumn{2}{|c|}{$\begin{array}{c}\text { TABLE } 3 \\
\text { Fercentage variation in } \\
\text { etimanated average costs }\end{array}$} \\
\hline MEAR & Shys \\
\hline $19 \times 5-1986$ & .00027 \\
\hline $1986-1987$ & 00056 \\
\hline $1987-1988$ & -0.0274 \\
\hline $1988 \cdot 1989$ & .0 .0169 \\
\hline $1989-1990$ & 0.0288 \\
\hline $1990 \cdot 1991$ & .0 .0211 \\
\hline $1991-1992$ & .00135 \\
\hline $1992 \cdot 1993$ & -0.0148 \\
\hline $1993-1994$ & .0 .028 \\
\hline
\end{tabular}

** : Significant at the $1 \%$ level

* Significant at the 5\% level

* Signifficant at he $10 \%$ level

Figure 13: Different Approaches to Technical Change (Pooling Data Estimation)

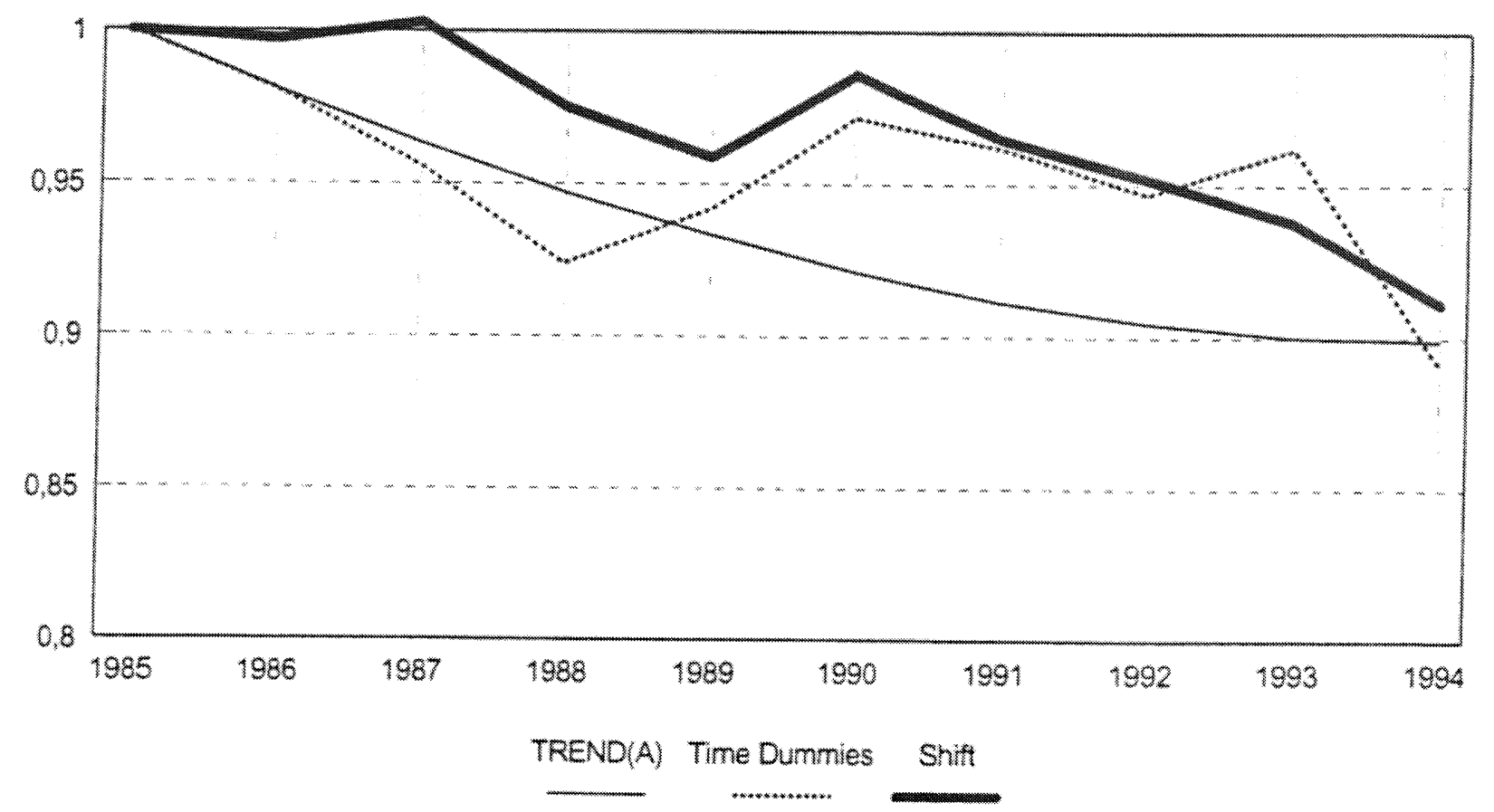

Source: See lext. 
Figure 14: Different Approaches to Technical Change

(Panel Data Estimation)

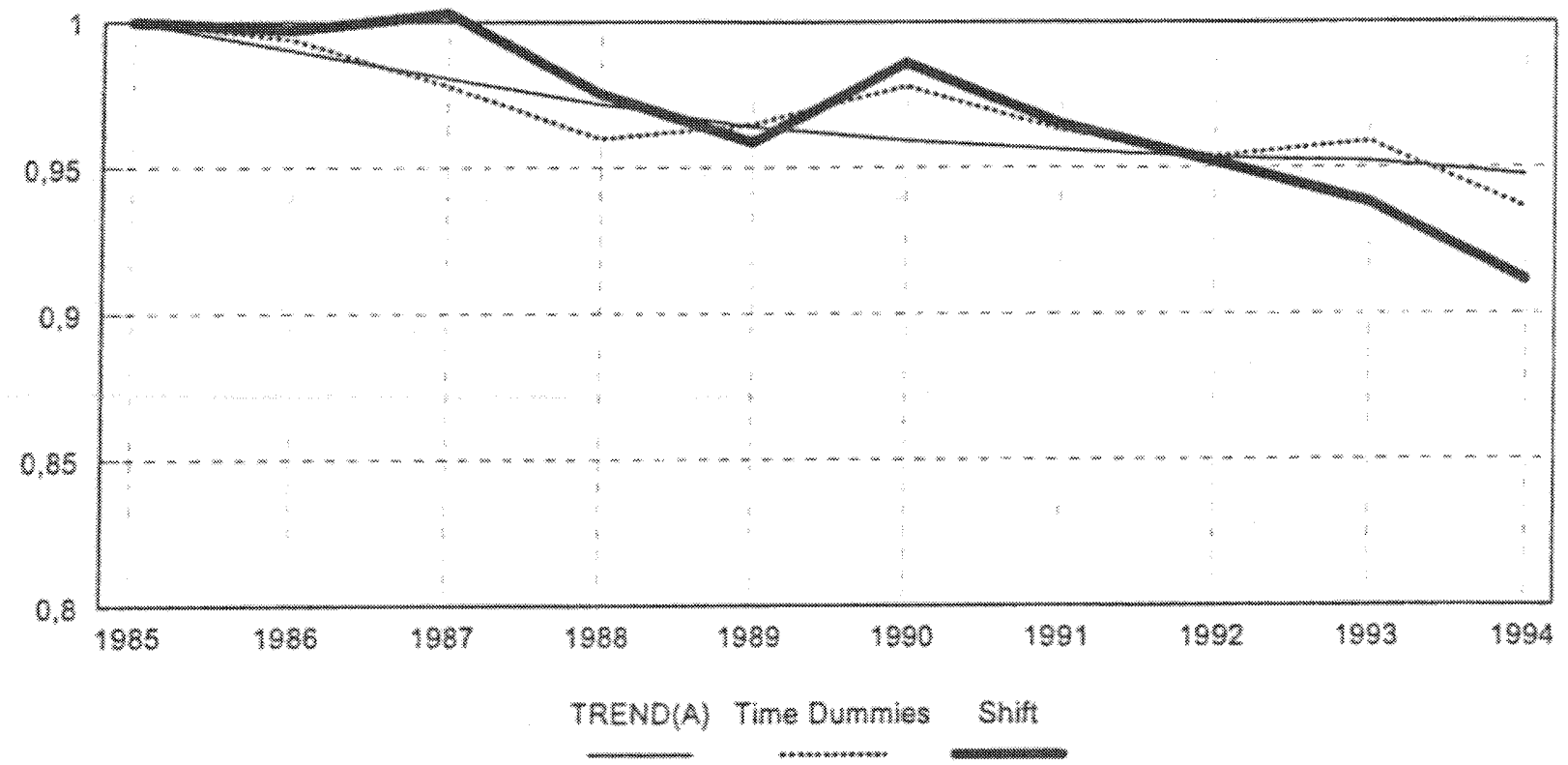

Source: See lext

However, our results are in contrast with those obtained in Lozano (1994) and Grifell and Lovell (1994 and 1995). Lozano (1994) estimates a thick frontier costs function for the commercial and saving banks sector over the period 1985-1991, obtaining technical regress in both subsectors of the banking system using the time trend approach. Two can be the possible explanations of the different results: 1) Lozano (1994), instead of deflating all nominal variables as we have done in this work, only deflates the output variables; 2) Lozano (1994) consolidates backward merged institutions whereas the present paper does not.

There is no consensus in the banking literature in the way of treating (nominal versus real) the costs and input prices in the estimation of the cost function. The referee suggested us to check the robustness of the results when the costs and inputs prices are expressed in nominal terms. In this case, for the complete period 1985-94 the results obtained for the different approaches to the technical change are the following:

\begin{tabular}{|c|c|c|c|c|}
\hline $\begin{array}{c}\text { urend } \\
\text { (pooning drats) }\end{array}$ & $\begin{array}{c}\text { wretud } \\
\text { bantel data }\end{array}$ & $\begin{array}{c}\text { tome dummies (poohing } \\
\text { data) }\end{array}$ & $\begin{array}{l}\text { hime dummies (panel } \\
\text { data) }\end{array}$ & shit \\
\hline $\begin{array}{l}\text { D.634 } \\
(3.525)\end{array}$ & $\begin{array}{l}\text { w1.0034 } \\
(-0.5505)\end{array}$ & $\begin{array}{c}0.03 \pi \\
(201732)\end{array}$ & $\begin{array}{c}0034 \\
(18.9399)\end{array}$ & 0,0850 \\
\hline
\end{tabular}

What these different results are suggesting is that, although the two different approaches are correct in theory, both can give different empirical results. As pointed by the referee the different results might be indicating that the linear homogeneity restriction is rejected by the data. 
Grifell and Lovell (1994) obtain productivity decline over the period 1986-91 for the savings banks sector using a Malmquist indexes approach. This different result can be due to the fact that the number of three different accounts (loans, savings and services), instead of the number of transactions (proxy by the output in real terms) is used as a proxy variable of the banking output.

Our results allow us to conclude that when deregulation takes place (1990) it produces negative effects. Actually, the elimination of interest rate regulation, of the ban on branching and the reduction in investment and reserve requirement coefficients, puts banks into a temporary disequilibrium situation, where some banks, in general the most efficient and most profitable ones, become quite active in raising loanable funds increasing their interest rates and gaining market share. The evidence for other countries shows similar results. Bauer, Berger and Humphrey (1991), Humphrey (1992) and (1993) find negative technical progress at the initial stages of a deregulation process (1980 for the United States). On the other hand, Berg Forsund and Jansen (1992) find on the contrary that for the Norwegian banking system the situation seems to be the opposite once deregulation starts (1984). However, this evidence does not contradict our previous reasoning, since these authors argue that the Norwegian banks seem to have anciticipated the deregulatory process, having originated an initial excess capacity that was eliminated once the deregulation process was on its way.

\section{TECHNICAL CHANGE AND FIRM SIZE}

In this section we address the question of whether technical progress affects banks in a different way according to size. Figures $4-9$ confirmed the presence of different ratios as a result of a heterogeneous behavior by firm size. To check on this different pattern, we estimate the impact of technical change for different bank sizes. We use the approaches that have been explained in section 5 except for the shift technique which, to estimate the cost function, requires too high a number of annual observations ${ }^{10}$.

Alternatively, for the time trend approach, we could estimate the impact of technical progress for groups of banks of different sizes substituting in equation (2) the mean values of the variables for such groups. However, the drawback of this strategy is that one implicitly assumes that the estimated parameters of the cost function are the same for the whole sample. an assumption that may not be the correct one. 
According to asset size, two different bank groups have been considered, with a dividing line of pts 150.000 millions. A higher number of bank sizes could not be considered due to the insufficient degrees of freedom left out in the regressions.

Table 4 reports the results on the impact of technical change using the time trend approach (equation (2)) based on the estimation of equation (1) for the two subsamples and the results corresponding to time dummies approach (last column). The results show that when data are pooled, "small" savings banks experience a higher impact of technical progress over the whole period, independently of the indicator used for technical change.

\begin{tabular}{|c|c|c|c|c|c|}
\hline \multicolumn{6}{|c|}{$\begin{array}{c}\text { TABLE } 4 \\
\text { Technical change by sizes: } 1985-1994\end{array}$} \\
\hline Thousands & \multicolumn{5}{|c|}{ Pooling Data Estimation } \\
\hline SIZE & $\operatorname{Trend}(A)$ & $\operatorname{Trend}(B)$ & Trend(C) & Trend(D) & Time dummies \\
\hline $0-150$ & $-0.0158^{* * *}$ & $-0.0222^{* * *}$ & $-0.0348^{* * *}$ & $-0.0284^{* * *}$ & $-0.0125^{* * *}$ \\
\hline+150 & $-0.0109^{* * *}$ & $-0.0168^{* * *}$ & $-0.0336 * * *$ & $-0.0219 * * *$ & $-0.0055^{* * *}$ \\
\hline \multicolumn{6}{|c|}{ Fixed Effects Estimation } \\
\hline SIZE & $\operatorname{Trend}(A)$ & Trend(B) & Trend(C) & Trend(D) & Time dummies \\
\hline $0-150$ & -0.0014 & -0.0011 & -0.0019 & -0.0006 & 0.0002 \\
\hline+150 & $-0.0045^{* *}$ & $-0.0061^{*}$ & $-0.0134^{*}$ & $-0.0087^{*}$ & $-0.0085^{* * *}$ \\
\hline
\end{tabular}

*** Significant at the $1 \%$ level

** Significant at the $5 \%$ level

* Significant at the $10 \%$ level

By contrast, when we estimate the fixed effects model, the impact of technical change experienced by large savings banks is higher than that experienced by the smaller ones, the latter not being statistically significant.

Once more, similarly to the results in table 1 , the impact of technical progress for large banks is reduced approximately by half when we consider the existence of individual effects ${ }^{11}$.

11 When we estimate the impact of technical change using a unique cost function for the whole sample the results are different. Large banks are those who experience a higher impact from technical change, independently of the econometric technique used. This different result is nothing but additional evidence of the argument raised by McAllister and McManus (1993) in the sense that the translog is a local approximation to the underlying cost function used to extrapolate and that. consequently, it can be subject to potential errors of specification. 
In the case of pooling data estimation, the results are coincident with those of the former approach, showing that small savings banks experience a higher impact from technical progress than the large ones. By contrast, in the case of panel data estimation, large banks are those who experience a higher rate of technical progress ${ }^{12}$.

Results appear in figure 15 where average total costs are represented on the right vertical axis and their accumulated variation on the left one. This figure shows that, most of time, large banks show smaller average costs and, also, higher cost reduction than small banks.

Figure 15: Accumulated var. Technical Change and Average Costs by Sizes: Levels (AC) and Accum. Change (TC)

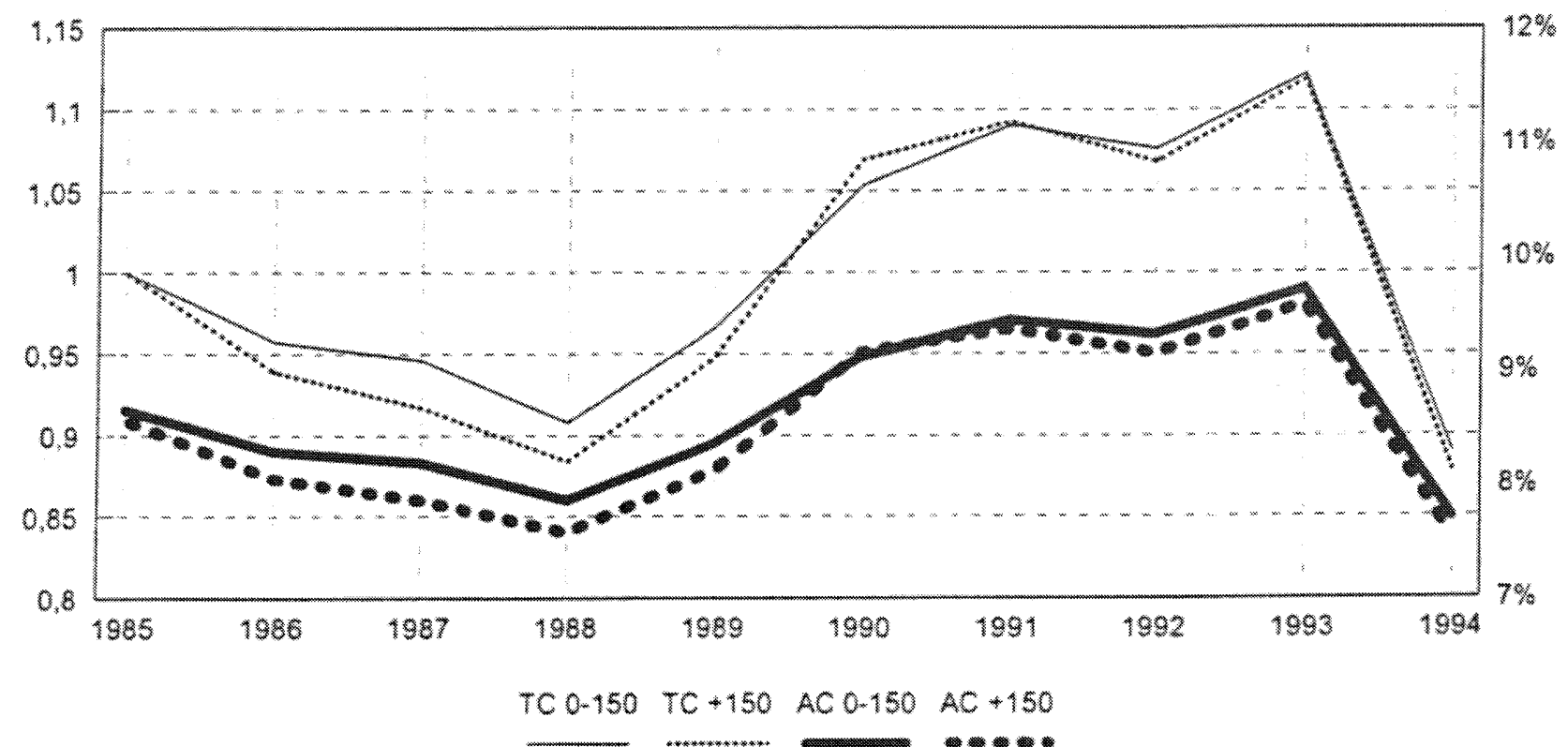

Source: See lext.

From a theoretical point of view, the concepts of technical change and economies of scale and scope are only applicable to the concept of efficient frontier (Berger et al. (1993), Charnes et al. (1993)). However, most of the studies consider an average cost function. This entails a conceptual problem that will be crucial in the interpretation of the results obtained from the regression analysis. Actually, as we have seen above, when we estimate cost functions, data pooling can be mixing technical change with efficiency. However, panel estimation captures better the influence of technical change because it can isolate the efficiency component. In fact,

"In this approach, the absence of crossed products with time dummies. makes the comparison of the results with those of the global sample impossible. 
as observed in figure 16, small firms are the most efficient ones. ${ }^{13}$ Thus, the superior technical change estimated for small firms using pool data can be contaminated by their higher level of efficiency.

Figure 16: Efficiency Levels vs Size

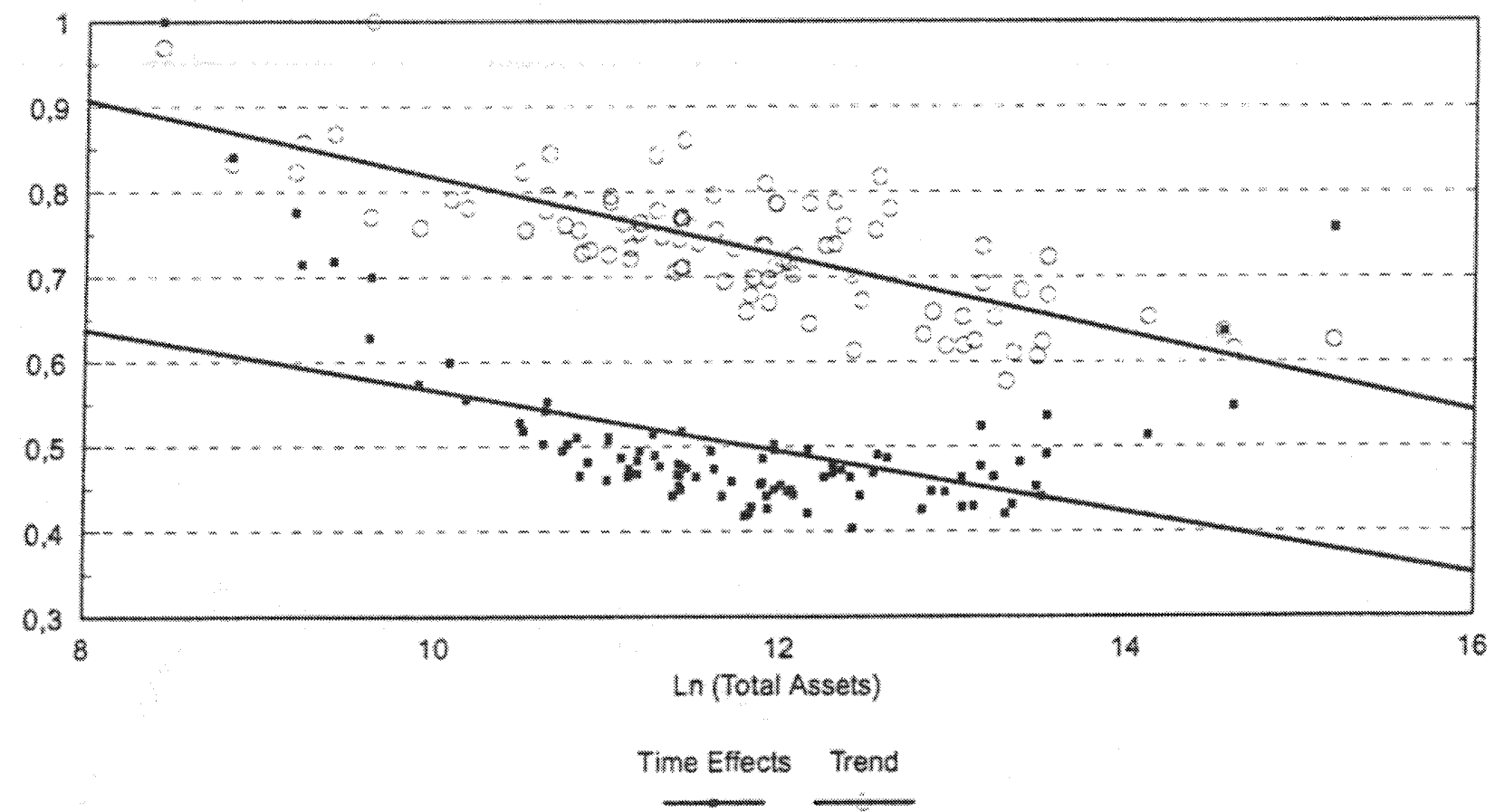

Source: See text.

\section{OPERATING COSTS}

As seen in section 2 (figure 6), financial costs amount to approximately $60 \%$ of total production costs for savings banks. For such reason, they dominate the behaviour of total costs which are in turn determined by the evolution of interest rates. In a similar way, the cost of raising funds were influenced by the increase in competition initiated after the "deposit war" that started once interest rates had been liberalized and legal coefficients had been substantially reduced.

Following Kumbhakar (1987) and Gong \& Sickles (1992) we compute efficiency measures ( $E_{\mathrm{i}}$ ) dividing the lowest fixed effect coefficient by the corresponding one of each bank in the sample $E_{i}=$ $\mathrm{R}_{\min } / \mathrm{R}_{\mathrm{i}}$. 
With the purpose of isolating our estimates of technical change from the evolution of financial costs and, therefore, of the role of competition and deregulation, we estimate in this section a cost function using only operating costs. In this way we obtain a stricter measure of the impact of technical change.

Our intuition is that savings banks have fought raising financial costs experienced during this period, with a reduction in operating costs that should give rise to a higher estimate of the impact of technical change. We estimate the translog cost function using data on operating costs and considering only, as inputs, capital and labor and excluding loanable funds ${ }^{14}$.

Tables 5, 6 and 7 contain the results on technical change using data panel techniques corresponding to the three approaches that were followed. In the time trend case, according to table 5 , it is found a statistically significant rate of technical progress of an annual $-1.94 \%$. If we compare this estimate with that obtained using total costs, we find an impact of technical change three times as high $(-0.68 \%)$. This result evidences the effort carried out by savings banks in reducing operating cost to compensate for the large increase in financial costs. This higher technical progress estimated using operating costs can also be obtained when we use the alternative indicators of technology (Trends (B), (C) and (D)).

Similar results are obtained if we use the time dummies approach (table 6), getting an annual rate of technical progress $(-1.93 \%)$ much higher then that obtained previously in table 2 $(-0.55 \%)$.

Table 7 shows the results corresponding to the shift cost approach. With the exception of the period 1989-90, for the rest of the decade, we find a much higher impact of technical change on operating costs than that obtained using data on total costs.

Figures 17 and 18 show the accumulated variation of operating costs due to technical progress corresponding to the three approaches used. Comparing them with figures 12 and 14 we can observe how the accumulated technical progress is quantitatively higher for operating costs, although the time pattern is quite similar to that of total costs. The existing differences with the shift cost approach are clearly highlighted.

${ }^{14}$ This implies the disappearance of the price equation associated to loanable funds $\left(\mathrm{P}_{2}\right)$. 


\begin{tabular}{|c|c|c|c|c|}
\hline \multicolumn{5}{|c|}{$\begin{array}{c}\text { TABLE } 5 \\
\text { Technical change in Operating Costs }\end{array}$} \\
\hline YEAR & Trend $(A)$ & Trend(B) & Trend(C) & Trend(D) \\
\hline 1985 & $-0.0231^{* * *}$ & $-0.0243^{* * *}$ & $-0.0229 * * * *$ & $-0.0231^{* * *}$ \\
\hline 1986 & $-0.0217^{* * *}$ & $-0.0247^{* * *}$ & $-0.0217^{* * *}$ & $-0.0223 * * *$ \\
\hline 1987 & $-0.0214^{* * *}$ & $-0.0260^{* * *}$ & $-0.0224 * * *$ & $-0.0227^{* * *}$ \\
\hline 1988 & $-0.0203^{* * *}$ & $-0.0257^{* * *}$ & $-0.0220^{* * *}$ & $-0.0221 * * *$ \\
\hline 1989 & $-0.0193 * * *$ & $-0.0233^{* * *}$ & $-0.0211^{* * *}$ & $-0.0215^{* * *}$ \\
\hline 1990 & $-0.0186^{* * *}$ & $-0.0223^{* * *}$ & $-0.0210 * * *$ & $-0.0213^{* * *}$ \\
\hline 1991 & $-0.0179 * * *$ & $-0.0211^{* * *}$ & $-0.0208^{* * *}$ & $-0.0212^{* * *}$ \\
\hline 1992 & $-0.0172^{* * *}$ & $-0.0197^{* * *}$ & $-0.0207^{* * *}$ & $-0.0214^{* * *}$ \\
\hline 1993 & $-0.0157^{* * *}$ & $-0.0181^{* * *}$ & $-0.0201^{* * *}$ & $-0.0207^{* * *}$ \\
\hline 1994 & $-0.0146 * * *$ & $-0.0172^{* * *}$ & $-0.0199 * * *$ & $-0.0206^{* * *}$ \\
\hline $\begin{array}{c}\text { Average yearly rate } \\
1985-1994\end{array}$ & $-0.0194^{* * *}$ & $-0.0228^{* * *}$ & $-0.0214^{* * *}$ & $-0.0218^{* * *}$ \\
\hline \multicolumn{5}{|l|}{ SIZES } \\
\hline $0-150$ & -0.0045 & -0.0015 & -0.0073 & -0.0035 \\
\hline+150 & $-0.0200^{* * *}$ & $-0.0205^{* *}$ & $-0.0458^{* * *}$ & $-0.0318^{* * *}$ \\
\hline
\end{tabular}

\begin{tabular}{||c|l|}
\hline \multicolumn{2}{|c|}{ TABLE 6 } \\
Technical Change in Operating Costs \\
\hline \multicolumn{2}{|c|}{ Time Dummies Approach } \\
\hline $1985-86$ & -0.0126 \\
\hline $1986-87$ & $-0.0420^{* * *}$ \\
\hline $1987-88$ & $-0.0317^{* * *}$ \\
\hline $1988-89$ & -0.0187 \\
\hline $1989-90$ & $0.0268^{*}$ \\
\hline $1990-91$ & $-0.0308^{* *}$ \\
\hline $1991-92$ & $-0.0355^{* *}$ \\
\hline $1992-93$ & -0.0047 \\
\hline $1993-94$ & $-0.0430^{* * *}$ \\
\hline Average yearly rate & \\
\hline $1985-1994$ & $-0.0193^{* * *}$ \\
\hline SIZES & $-0.0045^{* * *}$ \\
\hline $0-150$ & $-0.0200^{* * *}$ \\
\hline+150 & \\
\hline
\end{tabular}

\begin{tabular}{||l|l||}
\hline \multicolumn{2}{|c|}{$\begin{array}{c}\text { TABLE 7 } \\
\text { Technical Change in } \\
\text { Operating Cost }\end{array}$} \\
\hline \multicolumn{3}{|c|}{ Shift Cost Approach } \\
\hline $1985-862$ & -0.0418 \\
\hline $1986-87$ & -0.0591 \\
\hline $1987-88$ & -0.0633 \\
\hline $1988-89$ & -0.0346 \\
\hline $1989-90$ & 0.0351 \\
\hline $1990-91$ & -0.0500 \\
\hline $1991-92$ & -0.0506 \\
\hline $1992-93$ & -0.0306 \\
\hline $1993-94$ & -0.0821 \\
\hline
\end{tabular}

*** Significant al $1 \%$ level

** Significant al $5 \%$ level

* Significant at 10 level 
Figure 17: Time Trend and Technological Indicators of Technical Change: Operating Costs (Panel Data Estimation)

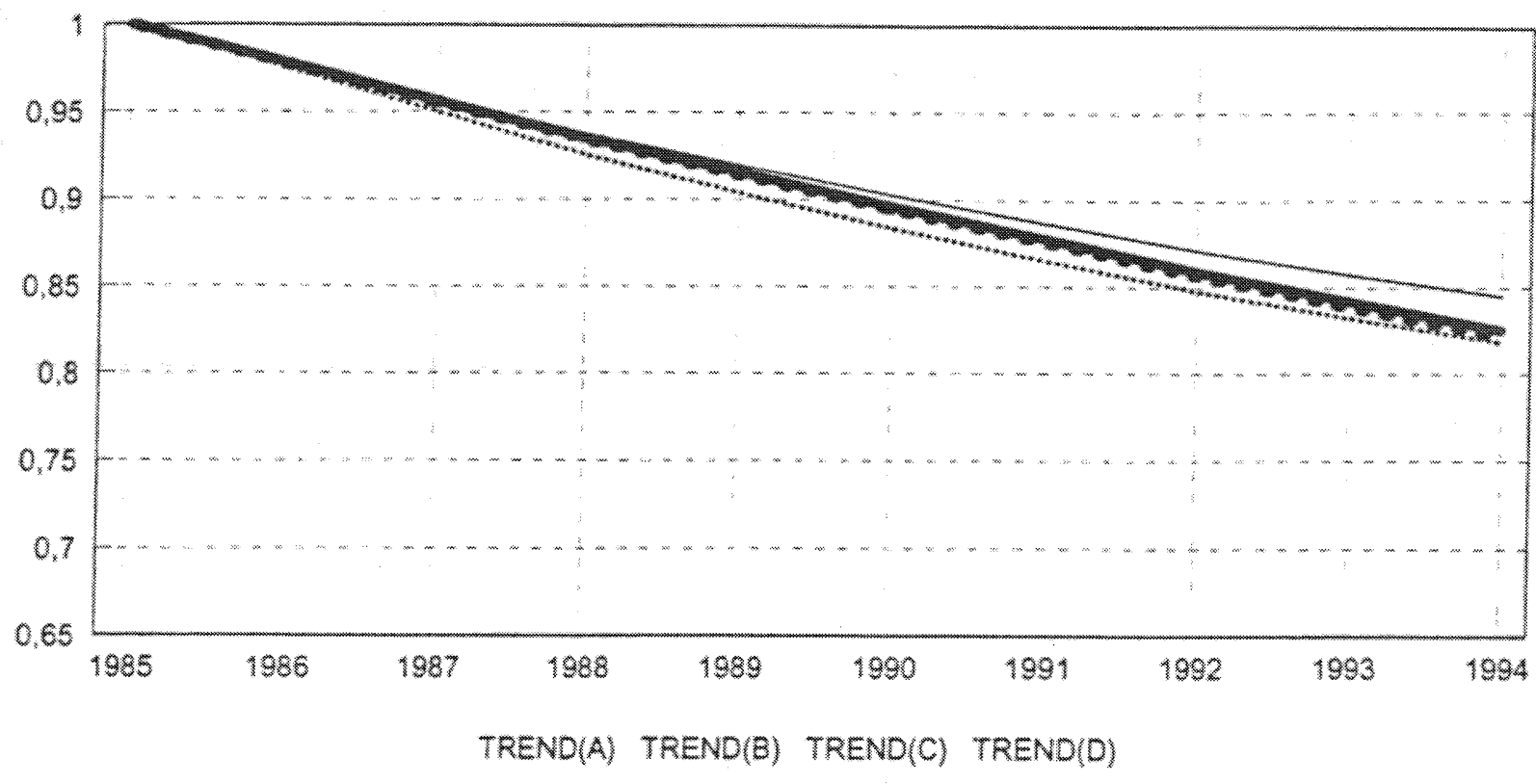

Source: See tex:

Figure 18: Diferent Approaches to Technical Change: Operating Costs (Panel Data Estimation)

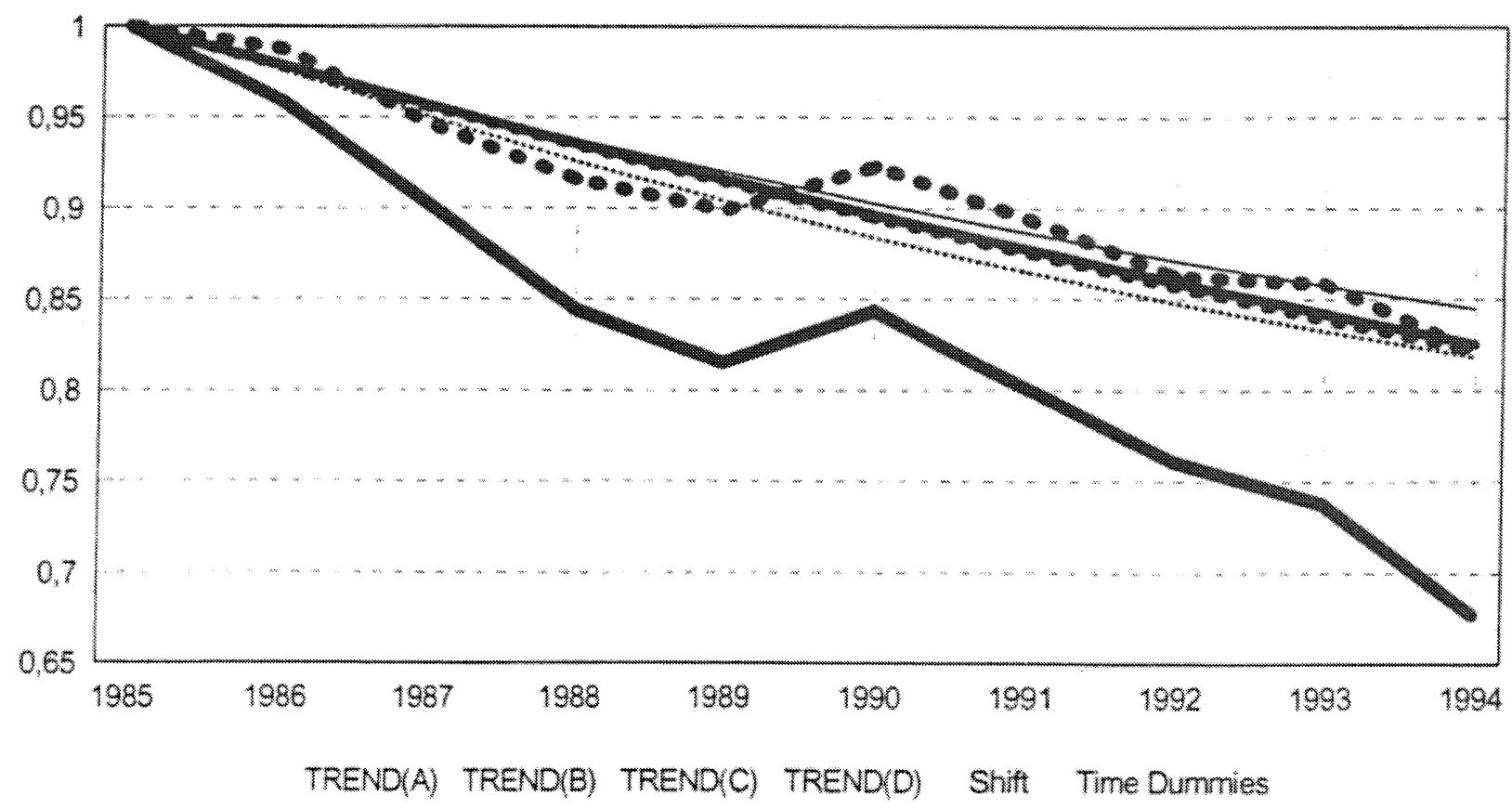

Source: See lext 
The results by size confirm our results in section 5 , since the largest savings banks are those who experience a higher rate of technical progress (panel data estimation). In contrast with the result shown in table 4 for total costs, operating costs for small savings banks do experience a significant reduction throughout the period. This result implies that small banks have also made an effort in reducing operating costs although in a lesser degree than the bigger banks, given their lower increase in financial costs (figure 5).

Summing up, the results using this stricter measure of technical progress show how our estimates of the impact of technical progress are higher than when we use a broader definition of technical change that includes the effects of deregulation and of an increase in competition. Likewise, the larger banks that have seen their financial costs increase at a higher pace are those who have experienced the largest reduction in operating costs.

\section{CONCLUSIONS}

The aim of this paper was the analysis of the influence on average costs of the Spanish savings banks arising from three main causes: a rapid deregulation process, the introduction of new technologies and a significant increase in competitiveness. Likewise, we draw a distinction between the influence of technical progress on total as opposed to operating costs. In the latter case we get a more adequate indicator of technical progress without taking into consideration the influence of deregulation and the increase in competition on financial costs.

To do so we estimate a translog cost function for the period 1985-94. Three different approaches are used: the introduction of an index of technical in the regression, the use of annual time dummies and the analysis of annual shifts in the cross section cost functions estimated for each of the ten years of the sample. Four indexes of technical change are used: a time trend and three different indicator of the diffusion of technology. All the results are derived using two alternative forms of treating the data; pooling the observations and using data panel econometric techniques. The main difference between these two techniques is that when using panel data techniques, we estimate a frontier costs function rather than a mean costs function.

We observe important differences in the estimates of the impact of technical change derived from the way data are considered. This is due to the fact that pool data estimation may capture as technical change what actually is a higher level of efficiency. In this respect, the fixed 
effects model enables us to isolate the efficiency component of each firm and generates more adequate estimates.

The results obtained using data panel techniques (frontier costs function) are the following:

1.- Over the last decade, the impact of technical progress on Spanish savings banks has been reflected in an accumulated reduction of average costs of roughly 5 to 10 percent, independently of the approach considered in the analysis. The estimated average impact of technical change on average costs from introducing a particular index of technical change runs from an annual rate of $-.89 \%$ for the credit and cash card indicator to $-.68 \%$ corresponding to the simple time trend.

2.- Similar results are obtained from the time dummies approach, with an annual rate of change of average costs of $-.64 \%$.

3.- Likewise, the outcome of the procedure involving the annual shift of a cross section estimated cost function gives similar results to those of the other two approaches. However, the accumulated level of cost reduction is not exactly the same; it exceeds that of the time dummies approach and it is smaller than that of the method based on the time trend. Furthermore, the annual behavior is much more irregular than the outcome shown by the other approaches. This is the consequence of the larger degree of flexibility of this procedure.

4.- The results that are obtained when we use a more adequate measure of the effect of technical progress like operating costs, we find a higher rate of technical progress. This finding is evidence of a real effort made by Spanish banks in reducing operating costs to compensate for the significant increase in financial costs, the result of deregulation and an increased competition.

5.- When splitting the sample into two different subsamples according to the size of banks, large savings banks are found more benefitted from total cost reduction than small banks and this is true even more in the case of operating costs. However, the levels of efficiency of small banks are larger than those of the large banks. This distinct level of efficiency justifies the different results obtained when using pooling or panel data, since under the former method it is attributed to technical progress what is due to a distinct level of efficiency. 